\title{
Gedagtes oor gekontroleerde eksegese
}

\author{
J A LOADER
}

\section{INLEIDING}

Gedurende die afgelope jare is daar veel gepraat en geskryf oor die metode waarop die Ou Testament geëksegetiseer word. Die hele vraag na ' $n$ verantwoordbare eksegetiese metode het besonder aktueel geword. Ook in Suid-Afrika is dit 'n veelbesproke onderwerp. Belangstelling word van alle kante getoon, ook binne die Hervormde Kerk. Daarvan getuig die opfrissingskursus van die Predikantevergadering wat in Junie 1977 gehou is, en ook die bywoning van 'n spesiale kursus aan die Universiteit van Pretoria deur predikante. Hierdie artikel beoog om 'n sketsmatige oorsig te gee van my sienswyses oor die metode waarop die. Ou Testament gehanteer moet word as ons hom regwil interpreteer. Uiteraard sal dit baie samevattend moet wees, want die onderwerp is so uitgebreid dat volledige boeke oor blote onderafdelings daarvan geskryf kan word. Die materiaal word op die praktyk van die predikant toegespits en maak nie daarop aanspraak om alle aspekte wat ter sprake kom, volledig te behandel nie. Ek hoop om in 'n aantal verdere artikels meer aandag aan besonderhede te gee en met aktuele voorbeelde te illustreer wat hier slegs aangeraak word.

\section{A Misverstande}

Die algemene taalkunde het gedurende die afgelope twee dekades fenomenaal ontwikkel. Dit het ook ingrypende konsekwensies vir ons hantering van literêre produkte, want sulke produkte is geskrewe dokumente wat niks anders besig as taal nie. En dit is weer van belang vir die eksegese van die Bybel, want die Bybel is niks anders as 'n versameling van geskrewe literêre werke nie. Ons glo wel dat hierdie spesifieke literêre versameling Gods woord is, maar dit neem nie weg dat ons menslike geskrifte in menslike tale in die Bybel vind nie. Hierdie insig in die menslikheid van die Bybel het groot klemtoon in die teologie van Karl Barth gekry (vgl Kirchliche Dogmatik I/2, pp 505vv) en vanweë sy invloed in Hervormde teologiese kringe ook hier te lande ingeslaan. Ek wil graag wys op die konsekwensies wat dit vir ons hantering van die Bybel het. In die eerste plek beteken dit dat ons nie nuwere wetenskaplike inligting opr menslike taal en literêre produkte kan ignoreer nie. Daarbenewens beteken dit dat ons verantwoordelik is om alle middele in werking te 
stel om hierdie menslike geskrifte in die Bybel te verstaan en uit te lê - as die Bybel enigsins vir ons belangrik is. Oor hierdie twee punte bestaan daar baie misverstande op die Suid-Afrikaanse teologiese toneel.

\section{Die nuwere ontwikkelinge}

Anders as by die Atheners vanouds, het iets nuuts dikwels die effek dat dit agterdog oproep. Dit is heeltemal begryplik, maar agterdog mag alleen in afwysing oorgaan as dit gefundeer en gemotiveer kan word. So 'n afwysende reaksie teenoor die konsekwensies van die nuwere linguistiek vir die eksegese en teologie het inderdaad ook in Suid-Afrika ingetree, maar sonder 'n grondige wetenskaplike fundering.

Die een manier waarop die afwysende reaksie hom uit, is in die vrees dat die belydenis deur die sogenaamde "nuwe metode" in gevaar kom. Wanneer 'n teks krities geanaliseer word met gewone letterkundige metodes, word gevrees dat die enigheid van die Bybel aangetas word en gevolglik ook sy gesag. Hierop wil ek sonder meer gerusstellend antwoord. Dit gaan hier alleen daarom dat die woord van God reg yerstaan en verantwoord uitgelê word. Dit is vir my moeilik om te begryp dat so 'n vrees wortel kan skiet in 'n teologiese teelaarde wat so sterk beinvloed is deur die Barthiaanse teologie waar waardering vir die menslike van die Bybel en die gevolglike oop deur vir die kritiese wetenskap voluit ernstig geneem word.

'n Ander manier van afwysing is onverskoonbaar. Daar word soms goedsmoeds gesê dat "hierdie nuwe metode" niks bydra nie en dat mens alleen moeite doen om te beland waar mens buitendien daarsonder sou uitkom. Die onverskoonbaarheid van sulke uitlatings is nie dàt hulle gemaak word nie, maar dat hulle onverantwoord en ongemotiveerd gemaak word. James Barr het, byvoorbeeld, reeds in 1961 grondige wetenskaplike argumente aangevoer waarom die Theologische Wörterbuch zum Neuen Testament van Kittel en Friedrich aan ernstige bedenkinge onderhewig is. Nou kan ' $n$ teoloog nie meer eenvoudig sê dat Barr niks op dié punt bygedra het nie, en hy kan ook nie meer voortgaan om die Wörterbuch soos altyd te gebruik sonder dat hy Barr wetenskaplik kan weerlê nie Dit gebeur inderdaad, en uitsprake oor die onaanvaarbaarheid van die "nuwe benadering" word maklik gemaak sonder dat moeite gedoen word om vas te stel wat die wetenskaplike grondslae is van dit wat aangeval word. Soms word hierdie reaksie ook quasiwetenskaplik ingeklee. Daar word gesê dat die eindresultaat die belangrikste is en dăt, as die essensiële van die belydenis tog gehandhaaf word, daar geen sin te sien is in 'n aanpassing van ons eksegetiese werkswyse nie. Hierdie standpunt ignoreer die feit dat àl die metodes van die afgelope eeu in hul tyd nuut was, aanpassings geverg het en geweldig bygedra het 
tot ' $n$ beter insig in die rykdom van die Bybel. ' $n$ Variasie van quasiwetenskaplike beswaar is dat een ding afgewys word terwyl hy vir iets anders aangesien word. Teoloë beskou die konsekwensies wat vir die eksegese uit die taalkunde getrek word, soms as "strukturalisme". Dit gebeur omdat die struktuur van literêre werke belangrik is in die lig van bepaalde insigte wat die nuwere linguistiek uitgewys het. Maar die strukturalisme, waarmee dan die Franse strukturalisme bedoel word, is totaal iets anders en is nie eers num nie. Soms word van die swakste voorbeelde van Franse strukturalisme voorgehou om te "illustreer" hoe absurd die "nuwe metode" is. Dit is egter die gevolg van onvoldoende kennisname van wat aan die gang is, en so word appels met pere vermenigvuldig. Ons sal standpunte alleen kan afwys as ons moeite gedoen het om hulle goed te verstaan en as ons wetenskaplik kan aandui waar hulle verkeerd gaan.

\section{Pluralisme van Metodes}

Naas die eerste misverstand van wantroue teen nuwere ontwikkelinge is daar ook ' $n$ tweede. Dit is naamlik dat hier iets nuuts voorgestel word wat alles omvergooi wat vroeër gesê is en wat vir homself die. alleenreg opeis om die titel "korrek" te dra. Die idee bestaan dat die "nuwe metode" hovaardig is, dat hy net een aspek raaksien en verabsoluteer, en selfs dat hy onverantwoordelik op loop gegaan het met die linguistiek. Ook dit berus op gebrekkige inligting, want die omgekeerde word nou juis deur die "nuwe metode" bepleit. Meermale word daar, na my waarneming, alleen gesteun op die optrede van oorentoesiastiese studente. Ons kan dit goed waarneem in die etikette wat dikwels in besprekings by kongresse en elders aan die "nuwe manier" gehang word. Hy kry byvoorbeeld name soos "die semantiese metode" of selfs "semantiek" (wat verkeerd is omdat die semantiek alleen één faset is van die taalkunde wat brúikbaar is by die eksegese), "die linguistiese metode" (asof ons in die hantering van literatuurprodukte net met linguistiek alleen te doen het), of die "strukturele metode" of bloot "struktuuranalise" (asof die struktuur die enigste aspek van 'n teks is wat ons aandag verdien). Hierdie misverstande is soms afwysend bedoel en soms (veral by studente) positief-entoesiasties. Hulle is almal uitinge van die fout dat ons hier met 'n metodemonisme te doen het. Dit kom my voor asof dr D J C van Wyk hiervoor bevrees was toe hy sy hoofartikel in Die Hervormer, Oktober 1977, p 12, geskryf het. Hoewel dit'n gebalanseerde en versigtig bewoorde artikel is, ag hy dit nodig om te waarsku teen 'n oordrywing van die nuwere taalwetenskap. Dit is volkome korrek, soos ek hieronder sal betoog. Maar wanneer hy praat van "hierdie diskussie" waarin daar na sy waarneming eensydigheid ingesluip het, lyk dit my asof hy nie bewus is van die pleidooie vir die vermy- 
ding van eensydigheid en verabsolutering wat juis vanuit die taalwetenskap na die eksegese toe kom nie - sien hieronder.

Met 'n metodemonisme word in hierdie geval bedoel dat die konsekwensies van die linguistiek vir die Bybelse letterkunde lei tot die verabsolutering van een metodiese aspek. Juis die teenoorgestelde is die geval. Wanneer 'n Ou-Testamentiese teks geëksegetiseer word, is daar verskeie metodiese aspekte wat almal hul goeie reg en noodsaak het. Hierdie aspekte is te danke aan ons groot voorgangers in die eksegetiese wetenskap. So staan ons vandag op die skouers van hulle wat ons voorafgegaan het, hulle weer op die skouers van diegene wat hùlle voorafgegaan het en goeie werk vir hul tyd gelewer het, en so aan. Net so min as wat moderne motors ' $n$ ontkenning is van die waarde of funksie van ouer modelle, so min is nuwere insigte in die eksegetiese wetenskap 'n ontkenning van die waarde of funksie van die insigte van die verlede. Inteendeel, as dit nie vir ons voorgangers was nie, sou ons vandag veel minder kon vermag as wat wel die geval is.

As ons vir 'n oomblik ons oog laat gaan oor die ontwikkeling van metodes en rigtings in die eksegetiese wetenskap, sal hierdie punt geillustreer kan word. Ná die baanbrekende reformasie en die sewentiende- en agtiende-eeuse voorlopers van die moderne eksegese, het die bal vinniger aan die rol gegaan deur die werk van die groot Duitser, Julius Wellhausen. Die sogenaamde "literarkritische" metode het ontstaan waarin daar gewys is op die gelaagdheid in $\mathrm{Ou}$ Testamentiese tẹkste en hul ingewikkelde historiese verhouding tot mekaar. Hierdie aanpassing in die Bybelwetenskap het talle groot eksegete beïndruk en hul werkwyse beïnvloed. Hierna het Hermann Gunkel op die toneel verskyn en gewys op die fout dat die "literarkritische" skool te veel met die moderne outeurskapsgedagte werk en te min met vaste literêre vorms. (genoem Gattungen) soos klaagliedere, dankliedere ens. So het Gunkel en sy navolgers nie die werk van hul voorgangers van die tafel geveeg nie, maar die verdienstelike elemente daarvan oorgeneem en verryk deur nuwe dimensies te open. So het daar geweldige vordering in die Ou-Testamentiese wetenskap gekom sodat ons ons vandag nie kan voorstel hoe die wetenskap sonder Gunkel sou gelyk het nie. Op_sy voetspoor het die "traditionsgeschichtliche" metode ontwikkel. Hierdie metode het die belang van die voorskriftelike oorlewering.van die Ou-Testamentiese materiaal beklemtoon. Vandag word nog oral in die wêreld met wisselende klemtone op dié wyse gewerk. Groot name soos Albrecht Alt, Martin Noth en Gerhard von Rad sal altyd met die oorleweringshistoriese metode geassosieer bly. Die ekstreemste uitloper hiervan is die Skandinawiese tradisie-historiese skool waarvan Ivan Engnell 'n vooropstaande eksponent was en feitlik uitsluitend met mondelinge tradisies wou werk. Andere, soos die Spaanse geleerde Alonso-Schökel, het weer die belang ingesien van aandag aan die 
styl van die Bybelse tekste. Hier word gewerk met klank- en stylfigure, beeldgebruik ens. So kan ons praat van 'n stilistiese rigting wat ontstaan het.

Intussen het eksegete begin kennis neem van die konsekwensies van die nuwere lingnistiek vir die letterkunde en daarom ook vir die eksegese van die Bybelse letterkunde. Wat die Ou Testament betref, moet James Barr en Wolfgang Richter as die, baanbrekers geld. Hier kom die vraag na vore: Watter metode is reg? In die verlede is die verskillende metodes dikwels verabsoluteer. Gelukkig was daar egter ook baie geleerdes wat ingesien het dat hulle naas kritiek op hulle voorgangers ook veel van hulle kon oorneem en raffineer. Hierdie beginsel is presies wat ons moet probeer toepas. Dit is juis wat wetenskap beteken: Kritiese waardering. Die insigte van die "literarkritische" skool, die "formgescbichtliche" skool, die "traditionsgeschichtliche". skool en die stilistiese skool, in hul verskeie vorme. moet in die lig van ons nuwere insigte getoets, gekeur en verfyn word. Dan moet die waarheidselemente in hulle saam met dié uit die jongere ontwikkelinge geïntegreer word in 'n verantwoorde metode wat van al die afsonderlike "metodes" metodiesè aspekte maak.

Ons moet dan erns maak met verskeie metodiese fasette: Literarkritik, tekskritiek, struktuur, Gattung, inhoudsondersoek, historiese perspektiewe soos tradisiekritiek, en laastens redaksiekritiek. Die aard van sommige tekste veroorsaak dat sekere van hierdie aspekte meer op die voorgrond kom as andere, en by ander tekste lê die klem weer verskillend. In die aaneenryging van ' $n$ aantal wette soos byvoorbeeld in die boek Levitikus is die struktuur van die perikoop minder.dominant as in, argumentsonthalwe, 'n kunstig opgeboude psalm. In 'n korrupte teks is die tekskritiek weer meer prominent as in 'n teks waar die skriftelike oorlewering glad verloop het. Maar in prinsipe moet die eksegeet al die fasette (àl die middele tot sy beskikking!) ter sprake bring en kýk wat hulle oplewer.

Hierdie dominansie van sekere aspekte meer as ander na gelang die teks wissel, moet ons egter nie mislei tot 'n fout wat teoloë soms wel maak nie. Ditword onder woorde gebring deur dieclichédatdie aardvan die tẹs die metode bepaal. Dan word een metodiese aspek vir een teks gekies en die ander geïgnoreer, terwyl 'n ander aspek weer vir' $n$ ander teks uitgekies word. Dit is ' $n$ volkome subjektiewe eklektisisme, waardeur'n mens in staat gestel word om in 'n teks te vind wat jy wil deur net die "metode" te kies wat jy wil. Dan besluit die eksegeet eers watter sogenaamde metode geskik sal wees om geregtigheid aan die inhoud van 'n teks te doen, wat impliseer dat hy reeds (metodeloos) genoeg uitleg gedoen het om te weet watter metode nodig is. Dus kies hy natuurlik die metode wat gaan pas by wat hy_reeds_subjektief besluit het. Daarom moet àl die fasette van die metepluralisme toegepas word, en dan sal vanself blyk watter een (of meer) hulsèlf op die voorgrond bring. 
So het ons dan 'n gekontroleerde en toetsbare metodiese grondslag waarop ons werk. Daarin is verskeie metodes gereduseer tot metodiese aspekte met almal ewe goeie reg en noodsaak. Daar is onder hulle nie 'n rangorde nie, maar wel 'n volgorde. Dit bestaan in die onderskeid tussen sinchronie en diachronie. Die sinchroniese werk het te doen met dit wat daar staan soos dit daar staan, afgesien van historiese perspektiewe. Hier werk ons dus met teksimmanente eksegese. Diachroniese werk het te doen met ontwikkeling en historiese verloop. Hier gaan dit dus om die historiese perspektiewe in die eksegese. Die een groot pyler van die linguistiek se konsekwensies vir die eksegese is hier geleë. Die taalkunde het ons, sedert die werk van die groot Geneefse taalkundige, Ferdinand de Saussure, geleer dat sinchroniese aspekte altyd voorafgaan aan die diachroniese. Diachronie kan alleen op grond van die sinchronie bedryf word. Ons kan byvoorbeeld alleen vasstel wat die geskiedenis van ' $n$ woord se betekenis is (diachronie) as ons vooraf die verskillende voorkomste van daardie woord in verskillende tekste bestudeer het soos hulle werklik daar gebruik word (sinchronie). Dit geld nie net in die taalkunde nie, maar ook in die letterkunde waar ons te make het met produkte wat taal gebruik. Dit beteken dat historiese aspekte nooit die uitgangspunt in die eksegese kan wees nie. Sulke aspekte is baie belangrik, maar mag alleen volg nadat ons die teks soos hy daar staan (sinchronies) ondersoek en geanaliseer het. Daarvoor moet 'n teks eers afgegrens en struktureel ondersoek word sodat sy inhoud binne hierdie dissipline ter sprake kan kom. Dit is die teksimmanente werk. Eers daarna moet die historiese werk bykom. As die volgorde omgekeer word, word dit moontlik om die inhoud te laat bepaal deur dinge buite die teks. Dan kan die eksegeet maklik in die teks vind wat hy wil.

\section{B. Die metodefasette}

Wanneer ons nou 'n bietjie nader toesien, sal twee dinge uitstaan. Eerstens is die belydenis dat ons in die Bybel met Gods woord te doen het, nie 'n towersleutel vir die interpretasie nie. Die menslike van die Bybel maak dat ons ons moet oriënteer aan die feit dat ons met gewone literêre produkte te doen het. Dit beteken dat ons nie van 'n teologiese yoorveronderstelling as model vir die eksegese mag uitgaan nie. Natuurlik kan niemand hom totaal losmaak van sy voorveronderstellings nie. In 'n volgende artikel sal ek aandui hoe hierdie element van voorveronderstelling myns insiens sy regmatige aandeel kry. Nou gaan dit my alleen daarom dat hierdie voorveronderstellings nie die eksegetiese proses voorhands mag bepaal nie. Dit beteken verder dat die eksegese nie vanuit die dogmatiek beoefen mag word nie, maar omgekeerd moet die dogmatiek wel op grond van die eksegese beoefen word. Die tweede saak wat uitstaan, is die feit dat 
ons - soos hierbo aangedui - met tekste werk wat taal besig. Nou het die taalwetenskap ons geleer dat alle taaluitinge gestruktureerd moet wees om sin te maak. Dit wat ' $n$ stuk taal beteken, word uitgedruk nie in losstaande woorde nie, maar in betekenisdraende woordrelasies: Sinne wat op bepaalde maniere gebou (gestruktureer) is. Dit wat 'n outeur sê, word uitgedruk in sinne en in die aaneenskakeling van sinne. Daarom werk ons met sulke sinskombinasies of perikope. ? Die eenheid waarmee ons dus in die eksegese werk, is die parikoop - ? nie enkele verse of woorde nie. So 'n perikoop is dan ' $n$ bepaalde eenheid wat ' $n$ bepaalde skopus het; dit is die eenheid waarin die outeur ' $n$ bepaalde gedagtestrekking oordra. Deur hiermee te werk, doen ons geregtigheid aan konteks. Wanneer ons dit egter nie gedissiplineerd en verantwoord doen nie, word die ou slagspreuk van "teks binne konteks" waardeloos. Dr D J C van Wyk skryf in sy aangehaalde artikel dat die waardering vir konteks 'n baie ou insig in die teologie is. Hy het dit oor die nuwe taalwetenskap wat nie hierdie insig as sý prestasie kan opeis nie. Die punt is egter dat die taalwetenskap aangedui het hoe maklik ons in teorie die slagspreuk "teks binne konteks" kan aanvaar, maar in die eksegetiese praktyk nie kan aandui hoe dit werk nie. Ons kan maklik praat van konteks, maar volgens watter kriteria word die konteks in berekening gebring? Hoe gaan mens te werk om enkele deeltjies "nooit uit die geheel, uit die verband" los te maak nie? Sekerlik nie bloot op die gevoel af en sonder wetenskaplike maatstawwe nie. Wat kom van konteks tereg as ons dikwels preke hoor oor wat hamartia of katēcheo of $y d^{c}$ of ' $m$ n "eintlik" beteken, as lang stukke teologie ten spyte van die gemeenplaas "teks binne konteks" dikwels op sulke woorde gebou word?

1. As ons dan met perikope moet werk, is die eerste taak van die eksegeet om sy perikoop af te greas. Hiervoor is daar verskeie formele en inhoudelike kriteria. Die voorkoms van byvoorbeeld ' $n$ inleidingsformule toon dat 'n nuwe perikoop hier begin. Verder kan die woordeskat in twee opeenvalgende gedeeltes so aanmerklik verskil dat ons kan sien dat hier twee eenhede en nie een nie voorhande is. Inhoudelik kan daar spanninge in die materiaal voorkom. In Genesis 1 en 2 vind ons byvoorbeeld twee verskillende voorstellings van die skepping van die mens. Verder kan twee gedeeltes doeblette van mekaar wees, wat eweneens daarop dui dat hier twee en nie een perikoop nie teenwoordig is (vgl weer Gen 1 en 2). So gaan ons dan te werk om die perikoop af te baken.

2. Vervolgens moet die gedeelte tekskrities ondersoek word. Daarvoor het ons die tekskritiese apparaat in die Bybel en verskeie handboeke oor die tekskritiek tot ons beskikking. Hier wil ek alleen wys op 'n nuwere dimensie wat by die goed bekende insigte van die tekskritiek bykom. Elke element van die teks is tekskonstitutief. Dit wil sê dat elke deel daarvan bydra tot die geheel van die teks. Elke 
tekskritiese verandering beteken 'n verandering aan die hele teks en kan nie geïsoleerd beskou word nie (dus weer die ernstig neem van konteks). Daarom is al die verdere fases van ons werk afhanklik van wat hier besluit word. Nou mag dit goedskiks gebeur dat die eksegeet in die latere fases van sy werk argumente vind wat hom dwing om 'n vroeëre tekskritiese beslissing te verander. Dan beteken dit egter dat hy nie eenvoudig die tekskritiese verandering mag aanoring en voortgaan asof niks gebeur het nie. Want nou het hy die hele teks verander, en derhalwe sal hy alles wat.hy reeds gedoen het in heroorweging moet neem. So ' $n$ verandering kan byvoorbeeld ' $n$ belangrike struktuurmerker in die gedrang bring en gevolglik uitwys dat die perikoop'n ander struktuur het as wat die eksegeet vroeër gemeen het. Hiermee het ek iets aangeraak wat ook vir die volgende stappe geld: Wanneer ons so met verskillende metodiese fases werk, word daar vanself-'n kontrolesisteem in die werkswyse ingebou waardeur die eksegeet gedissiplineer word om telkens te hertoets wat hy reeds gedoen het.

3. Nou weet ons hoe die perikoop op eerste gesig daar uitsien waar hy begin en ophou en hoe die teks lyk. Maar-dié perikoop is nou ook op'n bepaalde manier opgebou. Dit wil sê die gedeelte het ' $n$ bepaalde struktuur. Hieraan sal ons aandag moet gee sonder om in 'n oorbeklemtoning te verval en 'n strukturalisme te gaan bedryf. As die inhoud yan'n gedeelte uitgedruk word in betekenisdraende woordrelasies en deur die aaneenskakeling van sinne, moet ons vasstel hoe hierdie eenhede dan in betrekking tot mekaar staan. Die beginsel kan met die allegorie van 'n huis geillustreer word. Die dak, mure, deure, vensters en fondament funksioneer alleen sinvol vir sover hulle elk 'n bepaalde plek in die geheel inneem, dit wil sê vir sover hulle in 'n bepaalde relasie tot mekaar staan. Die dak is sinneloos as dit onder in die struktuur voorkom en die fondament is absurd as dit bo-op die mure gelê word. So werk dit ook met 'n stuk letterkunde. Nou sal dit nie deug om hiervan te sê dat 'n mens eenvoudig met aanvoeling kan vasstel hoe ' $n$ bepaalde perikoop gestruktureer is nie. By die waardering van enige letterkunde speel intuisie' $n$ belangrike rol, maar dit kan nie die laaste woord wees nie. Daar moet kriteria wees waardeur die eksegeet kan kontroleer en toets wat hy sê.

Die eenheid waarmee ons hier werk, hang af van die soort literatuur waarmee ons te doen het. In prosa is dit die kolon, en in poësie is dit die stige (versreël) wat naas die kolon gebruik kan word. 'n Kolon is.'n linguistiese sin. Dit wil sê nie bloot dié gedeelte wat ons gewoonlik met 'n hoofletter begin en met 'n punt sluit nie, maar 'n sin wat uit een hoofwerkwoordstuk en een hoofnaamwoordstuk bestaan. Dit kan ook beskryf word as 'n konstruksie wat nie lid is van 'n ander konstruksie nie. Die volgende is dus een kolon:

(Jan het gepraat) 
Maar die volgende is twee kola:

(Jan het gepraat) en (die man het geluister).

'n Stige is 'n metriese eenheid waarmee 'n digter sy gedig opbou (struktureer). In ' $n$ volgende artikel sal ek meer oor die indeling van kola en stiges sê en ook oor die kriteria waarvolgens ons hul verhouding tot mekaar (struktuur) kan vasstel. Hier gaan dit ons nog net om die beginsel. As voorbeeld kan die eenvoudige maar kunsvolle gedig van Psalm 113 gebruik word. Daar is een tekswysiging in verse 5-6 (sien die Biblia Hebraica). Toevallig kom die versnommers hier ooreen met die aantal stiges (behalwe die herhaalde halleluyah) sodat ek alleen die nommers in die tabel hoef te gebruik.

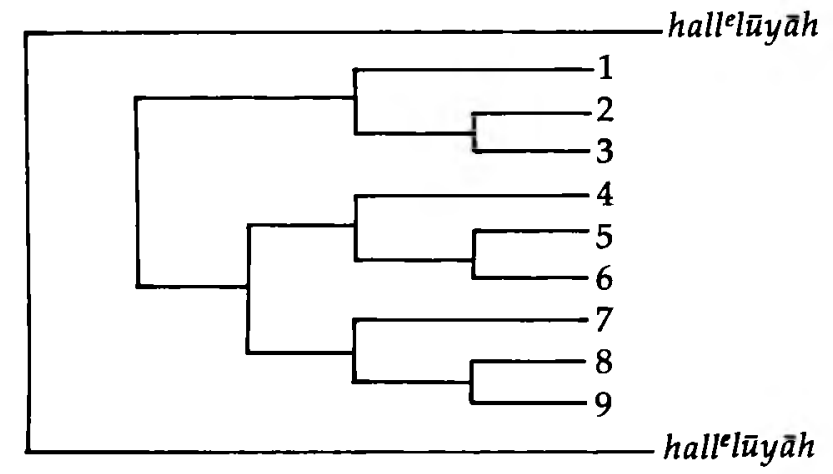

Almal kan sien dat die eerste hall le $\bar{u} y \bar{a} h$ korrespondeer met die laaste. Alles in die gedig word dus daardeur omspan. Vervolgens kry ons telkens een stige wat deur twee ander stiges uitgewerk word - dus drie gelykgeboude seksies. Die laaste twee seksies verbind weer aan mekaar (hier vind ons' $n$ uitwerking van die feit dat die hoë Yahweh laag aandag gee). Verder kom daar in die sewende stige 'n chiasme voor (verhef - uit die stof; uit die ashoop - verhoog), wat daarop dui dat die fokus van die psalm hier geleë is (die omkeer van verhoudings). So kan ons dan vasstel hoe die inhoudsmomente op die oppervlakte in betrekking tot mekaar staan. Ons het nog nie met die betekenis van die inhoud te doen gehad nie (dié kom eers in ' $n$ latere stap aan die orde). Wat ons wel gedoen het, was om die raamwerk waarbinne die betekenis funksioneer, vas te stel.

4. Nou kom 'n volgende aspek na vore. Tot watter tipe behoort hierdie perikoop? Ons moet nou ook vasstel watter Gattung deur die betrokke perikoop verteenwoordig word. Die struktuur van elke perikoop is uniek. Maar verskeie sulke unieke tekste kan ook bepaalde formele ooreenkomste met mekaar hê. Sulke tekste kan dan saam tot 'n tipiese groep gereken word, en so 'n tipiese groep heet 'n Gattung. Hoe meer ooreenkomste nodig is om aan die vereistes van ' $n$ Gattung te voldoen, hoe kleiner is die Gattung, en hoe minder, hoe groter 
word die Gattung. So kry ons in die psalms byvoorbeeld sowel klaagliedere as dankliedere. Maar wanneer ons nog verder onderskei tussen die klaagliedere, vind ons kleiner Gattungen soos die individuele klaaglied en die kollektiewe klaaglied. Wanneer liedere dus nog aan ' $n$ bykomende vereiste moet voldoen naas dié wat vir klaagliedere in die algemeen geld (naamlik dat dit in die eerste persoon enkelvoud moet wees), dan vind ons minder liedere wat dié element bevat en die Gattung word kleiner. Die vraag na die Gattung is belangrik vir sistematiese studie van die Ou Testament, maar kan ook bydra tot ons begrip van die inhoud van 'n teks. Wanneer ' $n$ profeet byvoorbeeld in sy kritiekprediking gebruik maak van die tipiese Gattung van die klaagsang, is dit ' $n$ effektiewe manier om tot die betekenis by te dra (vgl Amos 5:1 vv).

5. Vervolgens moet ons die inhoud ondersoek, dit wil sê die betekenis van die inhoud binne die strukturele raamwerk wat ons vasgestel het. Geillustreer aan ons voorbeeld van Psalm 113, sou ons die volgende kon sê: Eerstens vind ons die motief van Gods eer, veral in die eerste seksie gekonsentreer. In die tweede seksie kom die motief van sy hoogheid voor en in die derde sy neerbuiging na die armes. Maar stige 6 toon dat sy hoogheid juis bestaan in sy betrokkenheid met wat laag is. Dit beteken dat Hy sy eer daarin stel om ellendige mense op te hef (hier die motief van die ekonomiese minderbevoorregde en die sosiale verworpeling - respektiewelik die arme en die kinderlose). Die eer van God kan dus nie geskei word van die eer van mense nie. Wanneer Hy "afwaarts" ingryp, rig Hy ellendiges "opwaarts" (vgl die chiasme van stige 7 wat oorkruisloop en pas by die inhoudelike oorkruisloop van vernedering en verhoging). So is die skopus of gedagtestrekking van die psalm dan dat Gods grootheid juis daarin bestaan dat Hy genade betoon aan sosio-ekonomiese swakkes, en dit word met die lofroep hallelūy $\bar{a}$ omspan. Gods grootheid bestaan ook in ander dinge, maar daarop word nie in hierdie psalm gefokus nie. Dit word hier nie weerspreek nie, maar kom ook nie hier ter sprake nie. Daarom kan 'n eksegese van hierdie psalm ook nie daaroor handel - so asof die ander aspekte van Gods grootheid uit hierdie psalm uitgelê kan word nie. Gaan probeer ons dit wel doen, dan dra ons gegewens van buite die teks in - en dit is nie uitleg nie. Dan steur ons ons ook nie aan die funksie van hierdie bepaalde konteks nie. Dit is nog 'n manier waarop ons so ongesiens ons eie slagspreuk van getrouheid aan die konteks oorboord kan gooi.

6. As ons nou vasgestel het wat die inhoud van die perikoop beteken (waaroor nog veel meer gesê kan word as wat hierbo voorkom), het ons sinchronies gewerk. Maar nou is daar nog twee aspekte wat aan die beurt moet kom. Die eerste hiervan is die ondersoek na tradisiemateriaal en die beligting van die teks met historiese perspektiewe. Dit is dus diachroniese werk. Soms is dit van groot betekenis en soms van minder. Wat Psalm 113 betref, is laasgenoemde die geval. 
Ons ken die element van armvroomheid uit die na-eksiliese tyd, maar ook vroeër kom dit in verband met die Sionstempel voor. Daarom mag ons hier te doen hê met ' $n$ tradisie van vóór die ballingskap wat daarna gekontinueer is. Dan kan ons die lied met bepaalde gedeeltes van Deuterojesaja vergelyk (byvoorbeeld Jesaja 54:1). In ander gevalle, byvoorbeeld Esegiěl 37:1-14, is dit weer anders: Daar is die herlewing van die doodsbeendere alleen verstaanbaar teen die agtergrond van die ballingskap waaruit die verdorde volk sal herlewe. In elk geval mag ons nie by hierdie historiese ondersoek begin nie. Dit lei tot raaiwerk en inlegkunde. 'n Voorbeeld hiervan is Hans-Joachim Kraus se psalmkommentaar, waar hy van Psalm 113 sê dat dit 'n himne is en deur priesterkore gesing moes gewees het. Daarom eksegetiseer hy die inhoud in terme van subjektiewe gedagtes oor die historiese agtergrond en mis hy die hele punt waarom dit gaan.

7. Ons laaste metodefaset heet redaksionele andersoek. Hier kyk ons na die moontlikheid dat latere redakteurs die verskillende eenhede in groter stukke verwerk het. Dit kan dikwels gepaard gaan met 'n nuwe interpretasie wat die redakteurs aan eenhede gegee het. Vergelyk byvoorbeeld weer Esegiël 37, waar die gedeelte oor die doodsbeendere só geredigeer word dat daar ook sprake is van die opstanding van die dode. Nou sien ons dat daar twee vlakke is waarop die gedeelte funksioneer (die geestelike herlewing van die volk, en die opstanding van die dode). Beide is legitiem en die een kan nie ten koste van die ander verwaarloos word nie. Wanneer ons die redaksie van 'n stuk nagaan, moet ons dit met sinchroniese kriteria doen. Ons moet dus in die teks self die aanduidings vind waarop ons oordeel gebaseer word, en nie in subjektiewe idees oor wat moontlik kòn gebeur het nie. Dus weer: Diachronie op grond van sinchronie.

Wanneer ons ons teks so deurgewerk het, kan ons beweer dat ons alle middele tot ons beskikking aangewend het om vas te stel wat daar staan. Ons het geen metode verabsoluteer nie en ons het erns gemaak met die twee vernaamste perspektiewe wat die nuwere linguistiek vir ons geopen het: Ons het die konteks verantwoord verdiskonteer en nie alleen maar beweer dat ons dit met die ou insig van "teks binne konteks" eens is nie. En ons het ook sinchronie vóór diachronie beoefen. As ons weet wat daar in ons Ou-Testamentiese teks staan, moet ons vervolgens ook na die teologiese draagkrag daarvan vra. Daaraan sal ek in 'n volgende artikel aandag gee.

\section{EKSEGESE VAN DIE OU TESTAMENT EN DIE VERVULLING DEUR CHRISTUS}

In hierdie artikel wil ek voortgaan waar ek met my vorige bydrae ("Gedagtes oor gekontroleerde eksegese") opgehou het. Daar het ek 
betoog dat 'n gedissiplineerde metode om die Ou Testament uit te lê, nie alleen moontlik is nie, maar ook noodsaaklik. Die eerste taak van die eksegeet is, het ek probeer aandui, om onbevange te sê wat 'n Ou-Testamentiese teks sê soos hy daar staan en soos hy funksioneer binne' $n$ bepaalde historiese situasie. Dit is uit-en-uit 'n wetenskaplike saak.

Maar nou glo ons ook dat die Ou Testament die woord van God is. En ons glo ook dat Christus die vervuller van die Ou Testament is. Dit kan ons nie wetenskaplik bewys nie. Dit is 'n saak van geloof. Met ander woorde, hier het ons te doen met 'n geloofsveronderstelling of 'n voorveronderstelling. Hier kom ons nou by die element van voorveronderstelling waarna ek in my vorige artikel verwys het. Hierdie geloofsveronderstelling mag nie die metode waarvolgens ons ons wetenskaplike uitleg doen, bepaal nie. Dit sou beteken dat ons, in stryd met wat ons elders in the Hervormde tradisie afwys, die Christelike wetenskap beoefen. In Hervormde kringe word daar graag aanvaar dat wetenskaplike metode in geen dissipline deur die geloofsveronderstellings van die beoefenaar bepaal mag word nie. Maar ons wyk maklik hiervan af wanneer ons met die Bybelwetenskap te doen het. Baie voorbeelde kan genoem word van hoe die $\mathrm{Ou}$ Testament geëksegetiseer word in terme van wat ons oor sy vervulling glo. Dan is eksegese egter nie wetenskap nie - tensy ons bereid is om die idee van die Christelike wetenskap te aanvaar.

Ons geloof dat Christus die vervuller van die Ou Testament is, beteken dat die hele tradisie van die Ou Testament op Hom as die kulminasiepunt uitloop. Jesus, soos ons by die sinoptici verneem, en die breë Nuwe-Testamentiese tradisie beskou die Ou-Testamentiese tradisie as die raamwerk waarbinne sy verlossingswerk plaasvind. Vir die Nuwe Testament het die Oue sy vervullingspunt bereik en daarom legitimeer Christus die hele Ou Testament. Dit glo ons en dit het vir ons teologiese betekenis. Maar hoe hanteer ons dit?

Een van die maniere waarop die vervullingswerk van Christus sedert eeue tot vandag toe hermeneuties funksioneer, is in die sogenaamde belofte-vervulling-skema. Hiervolgens word die tekste van die Ou Testament as blote voorspellings van of vingerwysings na Christus beskou. Dit kan nie aanvaar word nie, want op so'n manier word daar vanuit 'n skema na die Bybel toe geredeneer. Dit doen geweld aan die eie aard en veelsoortigheid van die Ou-Testamentiese tekste. Sommiges mag voorspellings wees (van baie verskillende dinge), maar andere is weer wette wat byvoorbeeld die kultus van Israel in sý historiese situasie reël. Nog andere is berigte wat die destydse geskiedenis vertolk of himnes wat die lof van Yahweh in 'n bepaalde historiese situasie besing en nie van Christus praat nie (soos Psalm 113, wat ek as voorbeeld gebruik het). Die belofte-vervullingskema werk dan as 'n dwangbuis waardeur die eksegeet gedwing word om een of ander vorm van belofte in die Ou-Testamentiese teks 
in te forseer omdat hy meen dat Christus as vervuller dit noodsaaklik maak. Derhalwe word die betekenis wat die betrokke Ou-Testamentiese passasie in eie reg dra, geïgnoreer of kunsmatig iets wat hy nie sê nie in die mond gelê. Hier kan byvoorbeeld gewys word op die koningspsalms wat nie messiaanse voorspellings van Christus se koms is nie, maar oor die konings van Jerusalem gaan.

'n Ander tegniek is die allegorese. Hier word die vervulling in Christus as die "diepere betekenis" onder die woorde van die $\mathrm{Ou}$ Testament gesoek. Die allegorese is eerlik en erken uitdruklik dat dit hom nie gaan om wat daar staan nie, maar om 'n geheimsinnige betekenis waarna die teks sou verwys. Die klassieke voorbeeld hiervan is die allegoriese uitleg van die boek Hooglied. Omdat Christus die Ou Testament vervul het, daarom moet die boek verwys na die verhouding van Christus en sy gemeente. ' $n$ Antwoord wat moderne allegorici (en hulle kom nog steeds voor) skuldig bly, is waarom een boek of ' $n$ paar gedeeltes allegories uitgelê word en nie ook al die ander nie.

Die derde vorm waarin die belydenis van Christus as die vervuller van die Ou Testament hermeneuties funksioneer, word allerweë die tipologiese sisteem genoem. Hiervolgens word persone, instellings en gebeure in die Ou Testament as tipes of voorlopers van Christus beskou. Dit is dus ook 'n skema waarin die idee van voorafskaduwing voorkom, en werk dus in prinsipe soos die belofte-vervullingskema. Die instelling van die monargie in Israel, waarmee dan eintlik Juda bedoel word, word byvoorbeeld as ' $n$ tipe van Christus as die messias beskou, want daar is in albei gevalle van salwing sprake. Gewoonlik trek die voorstanders van die tipologie 'n skerp skeidslyn tussen hulle sisteem en die allegoriese sisteem. Daar word naamlik graag van die kategorie "geskiedenis" gebruik gemaak om die verskil tussen die twee te verduidelik. Aan die een kant, word gesê, hou die tipologie hom met breë historiese perspektiewe besig, terwyl dié aan die ander kant deur die allegorese geïgnoreer word. Maar hierdie onderskeid is nouliks houdbaar. Sommige vorms van tipologie het met historiese perspektiewe weinig te doen (byvoorbeeld persoonstipologieë soos Josef wat' $n$ tipe van Christus sou wees). Verder kan allegorie gebruik word om 'n skema te pas waar historiese gebeure wel 'n belangrike rol speel (byvoorbeeld die allegoriese uitleg waarmee Hooglied in verband gebring word met die handelinge van God met die historiese Israel of Christus se handelinge met sy volk - dus 'n heilshistoriese sisteem).

Die tipologie as ' $n$ hermeneutiese sleutel kan egter ook versigter en meer gesofistikeerd bedryf word. Daar kan onderskeid gemaak word tussen die tipologie van persone en instellings enersyds en historiese gebeure andersyds (vergelyk Martin Noth, "Die Vergegenwärtigung des Alten Testaments in der Verkündigung", Evangelische Theologie 12, pp 15-16). Dan kan daar verder geredeneer word dat Gods 
handelinge dade is en daarom lê die verbindingslid tussen die Ouen die Nuwe Testament hier. Dit sou beteken dat ons die voorkeur van die Nuwe Testament vir daad-gebeure moet waardeer en dienooreenkomstig met die Ou Testament as 'n verkondiging van dade omgaan. So ' $n$ sisteem is dus afhanklik van die Nuwe-Testamentiese gebruik van die Ou Testament. Dit sal nie werk nie omdat daar in die Nuwe Testament wel tipologieë van persone en instellings voorkom (byvoorbeeld Abraham, Abel, Noag, die tabernakel). Bowendien moet van geforseerde argumente gebruik gemaak word om te kan beweer dat dit in al die Ou-Testamentiese tekste om daad-tekste gaan; die $\mathrm{Ou}$ Testament is veels te pluriform daarvoor (vergelyk James Barr, Old and New in interpretation, Londen 1966, pp 111-112). Op hierdie wyse kan nie geregtigheid gedoen word aan die veelsoortigheid en genuanseerdheid van die Ou Testament nie.

Hierteenoor moet ons dan sê dat die lig van Christus retrospektief oor die $\mathrm{Ou}$ Testament gegooi word. As $\mathrm{Hy}$ die vervuller van die $\mathrm{Ou}$ Testament is en die hele Ou Testament legitimeer, beteken dit dat sy lig oor elke passasie van die Ou Testament gegooi moet word. Dit wil sê dat die skopus of boodskap van die betrokke passasie - wat onbevange eksegeties vasgestel is - soos wat hy met sy spesifieke nuanses en fynhede daar uitsien uit voor-Christus-terme in na-Christusterme vertaal moet word.

Ook hier kan ' $n$ mens jou toevlug tot 'n ander variant van die tipologie neem. Dit bestaan naamlik daarin dat daar gesoek word na tematiese ooreenkomste tussen die bepaalde Ou-Testamentiese gedeelte en die Nuwe Testament. Na my waarneming kom dit besonder dikwels voor. ' $n$ Voorbeeld hiervan is die uitleg van Psalm 23 oor Yahweh as die herder. Om dit vir die gemeente te laat spreek, word dan verwys na een of meer Nuwe-Testamentiese passasies waar die motief van die herder ook voorkom (byvoorbeeld Joh 10:1 vv en Heb 13:20) waardeur die Ou-Testamentiese teks dan vervul sou word. So word 'n Ou-Testamentiese motief of tema dan 'n tipe van die Nuwe-Testamentiese gedagte. Daar is verskeie redes waarom so 'n hermeneutiese tegniek nie kan werk nie. Eerstens is die Ou Testament drie maal so dik as die Nuwe Testament en kom talle Ou-Testamentiese temas net nie in die Nuwe Testament voor nie. Voorbeelde hiervan is die sinloosheidspessimisme van Prediker en die erotiese liefdesmotiewe in Hooglied. As mens vir sulke gedagtes geen teenhanger in die Nuwe Testament vind nie, kan hierdie tipologie nie aangewend word nie. Soms word daar skynbaar 'n Nuwe-Testamentiese teenhanger opgespoor. Dan kan dit wel voorkom asof die skema werk, wat egter in werklikheid nie die geval is nie. Wanneer byvoorbeeld vasgestel is dat die boek Job kritiek uitspreek teen 'n afleiding van sonde uit lyding, kan die hele impak van dié boek se boodskap verlore gaan wanneer' $n$ mens probeer om dit in die patroon van 'n bepaalde Nuwe-Testamentiese passasie te laat 
pas. Wanneer dit byvoorbeeld in terme van Hebreërs 12:5vv as liefdevolle tugtiging van God verklaar word, word die punt waarom dit in Job gaan, in sy teendeel omgekeer. Maar daar is ook ' $n$ dieperliggende rede vir die onaanvaarbaarheid van ' $n$ tematiese tipologie. Dit veronderstel naamlik dat die Ou Testament oorbodig is. Elke tema van die Ou Testament moet eers in die Nuwe teruggevind word voordat sy "teologiese betekenis" blyk. Met ander woorde, die $\mathrm{Ou}$ Testament maak alleen teologies sin vir sover dit wat hy sê in die Nuwe Testament voorkom. Selfs al sou mens met behulp van kunsgrepe en spitsvondighede kans sien om teenhangers vir al die $\mathrm{Ou}-$ Testamentiese temas in die Nuwe Testament te vind, sou daar nog geen antwoord gegee kon word op hierdie beswaar nie.

Verder beteken so ' $n$ werkswyse dat 'n Nuwe-Testamentiese teks die vervuller van die Ou Testament is. Selfs al sou die teendeel beweer word, beteken 'n tematiese tipologie dat een teks deur'n ander teks vervul word. Dit is hoe metodies te werk gegaan word - sonder inagneming van die feit dat die Woord vlees geword het, nie ' $n$ teks nie. Ook hier skuil daar ' $n$ innerlike inkonsekwensie wanneer bely word dat Christus die vervuller van die Ou Testament is terwyl die Bybel gehanteer word asof tekste die vervullers is. 'n Vierde beswaar teen hierdie veel voorkomende metode is dat dit die historiese karakter van die Ou Testament misken. Die Ou Testament kon nie sin gemaak of Gods woord gebring het as sy "teologiese betekenis" eers in die Nuwe Testament blyk nie. Maar die hele vervullingsgedagte is afhanklik daarvan dat die omgekeerde waar is. Die Ou Testament het wel sin gemaak en wel Gods woord gebring voordat Christus verskyn het, en moet dus as sodanig ernstig geneem word.

Tematiese tipologie werk gewoonlik met 'n Christosentriese openbaringsmodel, waarteen daar ernstige besware ingebring moet word. Dit beteken nie dat daar beswaar gemaak word teen 'n Christologiese teologie of 'n Christosentriese prediking nie. Inteendeel. Dit gaan nie hier om die theologoumenon dat Christus die middelpunt van ons teologie en prediking is nie, maar om die kunsmatige wyse waarop hierdie gegewenheid as 'n hermeneutiese model gebruik word. Dit wil sê die feit dat Christus in die sentrum staan, word gebruik as 'n sleutel om vas te stel wat die Ou Testament vir ons te sê het. Die kern van hierdie sienswyse is dat Christus die finale en ware openbaring van God is. Maar dan word gekonkludeer dat $\mathrm{Hy}$ daarom oral in die $\mathrm{Ou}$ Testament moet skuil. Een of ander mistieke teenwoordigheid van Christus in die Ou Testament is dus noodsaaklik. Nou is diegene wat met 'n Christosentriese openbaringsmodel werk lank nie almal mistici nie. Maar nogtans word daar ongemerk op ' $n$ fondament gewerk waarin so 'n mistieke sluitsteen ingebou is. Die wyse waarop die Bybel gebruik word, staan meermale in konflik met dit wat in ander verbande gesê word. Die inkonsekwensie is dikwels moeilik sigbaar omdat dit verhul word deur 
aanvaarbaar klinkende algemene uitsprake. In die onderhawige geval het ons 'n goeie illustrasie daarvan: Christus staan in die sentrum; die Ou Testament verkondig Christus; dus is Christus as Gods "ware openbaring" in die Ou Testament teenwoordig; derhalwe is die korrekte hermeneutiese proses om Nuwe-Testamentiese temas aangaande Christus te verbind met min of meer analoë temas in die Ou Testament, waardeur die Christologiese kwaliteit van die OuTestamentiese passasies dan duidelik sal word. As die ware openbaring van God egter alleen in Christus is, kan dit nie ook in die Ou Testament wees nie. Die konsekwensie hiervan sou wees om met Rudolf Bultmann te sê dat die Ou Testament in die Christelike geloof nie meer openbaring kan wees nie.

As ons met Gerhard von Rad wil instem dat die hele Ou Testament ooplê na 'n vervulling, en as ons glo dat Jesus Christus die vervuller en legitimeerder van die Ou Testament is, dan sal ons op ' $n$ ander wyse te werk moet gaan. In plaas van 'n bepaalde Nuwe-Testamentiese teks of tema moet die hele Nuwe Testamentiese kerygma, die implikasie van die ganse Christusgebeure op die betrokke Ou-Testamentiese passasie van toepassing gemaak word. So 'n Ou-Testamentiese teks is deur Christus vervul. Dit beteken dat dit deur Hom geldigheid bekom en in 'n nuwe dimensie verskyn. Daarom moet die lig van Christus retrospektief, vanuit die volheid van die tyd, teruggegooi word op die spesifieke gedagtepatroon wat ons onbevange eksegeties vasgestel het. Geillustreer aan die voorbeeld van Psalm 113 waarna ek in my vorige artikel verwys het, sal dit die volgende inhou: Gods eer bestaan daarin dat Hy ellendiges verhef; $\mathrm{Hy}$ bemoei Hom met sosiale en ekonomiese swakkelinge; dit is iets wat van die mens se kant deur lof omspan moet word. Dit is wat ons eksegeties vasgestel het - so sê die teks. En nou die lig van Christus: Die NuweTestamentiese getuienis toon hoe laag die hoë God ingegryp het om ellendige mense uit hul sonde- en doodsnood te verhef tot die kroon van eer. Maar die psalm praat spesifiek van ekonomiese en sosiale swakkelinge wat God ophef om 'n menswaardige bestaan in hul gemeenskap in te neem. Hy stel selfs sy eer daarin om hulle menswaardigheid te handhaaf. Daarom geld dit ook vir die Christusgelowige afgesien daarvan of hierdie tema ook in die Nuwe Testament voorkom of nie. Die tweede aspek van die psalm se teologiese draagkrag is dan dat God ook menswaardigheid op die alledaagse ekonomiese en sosiale terrein hoogag - as ' $n$ riglyn vir ons in ons bede, voorbede en lewenstyl. En die derde aspek is dat hierdie God wie se wil verheffing uit die doodsbande en ook uit die sosio-ekonomiese vernedering is, geloof en geprys moet word - dus die dankbaarheidsgedagte. So vertaal ons dan wat daar werklik in die Ou Testament staan uit voor-Christus-terme in na-Christus-terme (om die terminologie te gebruik van John Bright, The authority of the Old Testament, Londen 1967). Ons forseer dus niks in die Ou Testament deur van 'n al- 
gemeengeldende model gebruik te maak nie. Ons sê alleen wat hý sê en wat dit vir òns sê - alles omdat Christus deur sy vervullingswerk die Ou Testament gelegitimeer en vir ons geldig gemaak het.

Hierby wil ek ' $n$ nota voeg wat moontlike misverstand kan ondervang. Wanneer die lig van Christus retrospektief oor die resultaat van ons eksegese van Ou-Testamentiese tekste gegooi word, impliseer dit nie 'n ontkenning van die "prospektiewe" verhouding tussen die Ou Testament en Christus nie. Daarmee bedoel ek dat ons nie van die "bekende" Christus terugbeweeg na die "onbekende" Ou Testament nie. Inteendeel, ons kan nie verstaan wie en wat Christus is sonder die raamwerk van die Ou-Testamentiese tradisie nie. In die oorgelewerde Ou Testament vind ons "the mental, traditional, religious and verbal matrix in which Christ comes to be born" (James Barr, op cit, $\mathrm{p}$ 141). Histories is daar dus 'n beweging na vore ("prospektief") van die Ou Testament na Christus toe. Dit is die punt waarvan ek aanvanklik uitgegaan het. Maar juis omdat Christus aan die eindpunt van hierdie tradisie staan en omdat sy werk binne die raamwerk daarvan plaasvind, is dit nodig om die aspekte van die Ou-Testamentiese tradisie met die nuwe Christus-bedeling te belig (daarvoor het ek die term "retrospektief" gebruik).

Uit hierdie betoog sal dit ook duidelik wees dat daar 'n wesenlike verskil is tussen die wyse waarop ons die Ou Testament moet hanteer en die wyse waarop die Nuwe Testament dit doen. Die Nuwe Testament gebruik die Oue dikwels arbitrêr. Dit is egter geen vrypas vir ons om die Nuwe Testament na te doen nie. As die Nuwe Testament allegoriseer, tipologiseer of dergelike tegnieke gebruik wat wetenskaplik nie houdbaar is nie, gee dit ons nie die reg om die tydgebonde metodes van die Nuwe-Testamentiese skrywers oor te neem nie. Die klassieke voorbeeld hiervoor is die gebruik van Jesaja

7:14 in Matteus 1:23. Matteus gebruik die Jesajawoord as 'n bewys van die maagdelike geboorte van Christus, terwyl Jesaja nie van 'n maagd praat nie en bowendien nie 'n messiaanse voorspelling gee nie. Ons kan dus nie in sulke terme uit Jesaja 7 gaan preek nie. Daarmee word Matteus se uitspraak egter nie ongeldig of onaanvaarbaar nie. Die Nuwe Testament se aanvaarding van die Joodse Skriftradisie en "the importance of religious newness and creativity" (Barr, op cit, $\mathrm{p}$ 142) vorm die konteks van sulke passasies wat in die Nuwe Testament geïnterpreteer word, en nie die konteks waarin sulke passasies in die Ou Testament voorkom nie (vergelyk ook C F D Moule, The birth of the New Testament, Londen 1962, pp 53-85). Dus kan ons nie ons verantwoordelikheid om die Ou Testament op sigself wetenskaplik te hanteer, ontduik deur ons op die Nuwe-Testamentiese gebruik van sekere Ou-Testamentiese passasies te beroep nie. Ons hantering van ' $n$ Ou-Testamentiese gedeelte is een ding en ons hantering van die Nuwe-Testamentiese gebruik van daardie gedeelte is 
totaal 'n ander ding. 'n Preek uit Jesaja 7 sal totaal anders daaruit moet sien as 'n preek uit Matteus 1.

Ter afsluiting van die gedagtegang wat ek in hierdie artikel en in sy voorganger probeer ontvou het, kan nog een en ander gesê word oor die konsekwensies van so 'n hantering van die Ou Testament vir die prediking.

Prediking is nie eksegese nie, maar verkondiging waarin die resultate van die eksegese gebruik word. So is dit ook nie my bedoeling om die eksegetiese wetenskap op die terrein van die homiletiek te laat ortree nie. Maar as die prediking met die resultate van die eksegese werk, is 'n interdissiplinêre gesprek tussen die eksegeet en die praktiese teoloog baie sinvol. En omdat die predikant wat die kansel bestyg sowel eksegeet as homileet moet wees, is dit baie nodig. Dit is in prinsipe moontlik dat die wyse waarop gepreek word (dit wil sê die wyse waarop in die prediking van die eksegetiese resultate gebruik gemaak word), beïnvloed en selfs bepaal word deur 'n verkeerde hantering van die Bybel.

Dit gaan my hier om die tradisionele "teksprediking". Hieronder word verstaan die prediking oor 'n teksvers. Die vraag is hoe so 'n teksvers gekies word. Dit kan alleen gedoen word nadat die betrokke perikoop voluit ondersoek is met al die middele tot ons beskikking. Indien hierdie ondersoek uitwys dat vers $x$ die fokus van die perikoop in sy formulering vasvat, kan ons hom as "teks" of motto vir die preek gebruik - wat dan in elk geval die hele perikoop vir die gemeente verstaanbaar moet maak omdat dit die eenheid is wat die outeur gebruik het om sy sê te sê-en wat ons beweer te wil uitlê. Hierby kom twee punte ter sprake. Eerstens kan ons nie bloot sê dat ons enige "teks" eenvoudig in sy konteks uitlê sonder om teenoor onsself te verantwoord hoe konteks werk en wat die verhouding tussen so'n "teks" en sy konteks is nie. Tweedens beteken dit aan die ander kant nie dat 'n preek nie mag klem lê op 'n element wat resessief in 'n perikoop funksioneer nie. Resessiewe elemente kan belangrike elemente wees. Maar so 'n element funksioneer in relasie tot ander elemente in die betrokke perikoop. En hierdie relasie mag nie deur die klem wat 'n resessiewe element in die preek kry, verduister of geïgnoreer word nie. As die prediker klem lê op die onvergelyklikheid van Yahweh soos dit in Psalm 113:5 voorkom, is dit in orde. Maar dié klem moet die funksie van Gods onvergelyklikheid in Psalm 113 verdiskonteer. Daar dien hierdie motief om die omkeer van verhoudinge te onderbou. Baie dinge kan oor Gods onvergelyklikheid gesê word, maar nie in 'n preek wat die aanspraak maak om te verkondig wat die eksegeet uit Psalm 113 uitgelê het nie.

Hoewel prediking nie eksegese is nie, is daar 'n kategetiese element in die prediking. Daarom kan die ontvouing van 'n preek dikwels met vrug gemodelleer word op die struktuur van die perikoop. Dit beteken in geen geval 'n parafrase van die perikoop nie, maar wel 
'n verduideliking van wat die prediker in sy studeerkamer geëksegetiseer het. Indien parafrases van perikope of 'n reeks mini-preke in een preek voorkom as gevolg van 'n poging om "perikoopprediking" toe te pas, is dit foute wat uitgewys moet word. Sulke foute kan nie gebruik word om 'n karikatuur van die "nuwe metode" te ontwerp en dié dan op sulke gronde te kritiseer nie. Ons kan nie die gevaar van parafrasering of mini-preke omseil deur ' $n$ verkeerde Bybelgebruik nie.

So, dink ek, leer die gemeente wat in die Bybel stáán en wat dit vir hulle betéken. Ons maak dit so vir die gemeente moontlik om die verband te sien tussen wat ons sê en wat geskrywe is. Hulle hoor en aanvaar dan nie alleen die waarheid op gesag van die dominee nie, maar begryp ook dat en hoe dit uit die Bybel kom.

\section{DIE BASIESE EENHEID IN STRUKTUURANALISE}

In die eerste artikel van hierdie reeks ("Gedagtes oor gekontroleerde eksegese") het ek gesê dat 'n perikoop eers afgegrens moet word en tekskrities ondersoek moet word voordat ons by die analise van sy bou kan uitkom. Hiervoor is daar bepaalde kriteria. Dit is so omdat elke deel van ' $n$ teks tekskonstitutief is. Elke onderdeel dra by tot die geheel van die teks. Daarom kan ons nie eers 'n struktuuranalise maak en agterna besluit om byvoorbeeld ' $n$ tekskritiese verandering aan te bring nie. So 'n verandering kan naamlik die bou van die hele perikoop beïnvloed. Maar aan die ander kant kan 'n struktuuranalise wel kontrolerend werk ten opsigte van die voorafgaande fases van die arbeid. Ons kan byvoorbeeld deur die resultaat van ons struktuuranalise besluit om 'n vroeëre beslissing in heroorweging te neem. So is dit moontlik dat 'n verkeerde afgrensing van ons perikoop deur die struktuuranalise uitgewys word. Wanneer so iets gebeur, gaan daar' $n$ rooi liggie aan om te wys dat ons weer voor moet begin. So het ons in ' $n$ metodepluralisme altyd 'n ingeboude kontrolesisteem waardeur die voorafgaande stadia van die werk voortdurend aan hertoetsing onderworpe is.

Hierdie artikel is gewy aan die eenheid wat ons gebruik om die bou van 'n perikoop te bestudeer. Dit gaan dus om die basiese prinsipe wat hier in die spel kom en nie om 'n volledige analise van 'n hele perikoop nie. Daarom sal ek nie nou uitvoeriger handel oor die kriteria vir afgrensing en tekskritiek nie - alhoewel dit natuurlik wel ter sake is by aktuele tekswerk.

\section{A. Die kolon}

Soos ons in my aangehaalde artikel gesien het, moet alle taaluitinge gestruktureerd wees om sin te makk. Hierdie insig van die linguistiek het vir ons besondere waarde wanneer ons die sin van bepaalde 
taaluitinge in die Bybel wil nagaan. Omdat dit 'n basiese kenmerk van taaluiting is, moet ons 'n objektiewe kriterium vind wat ons in staat sal stel om die struktuur van die taaluiting na te spoor op ons pad na die betekenis daarvan. Hierdie kriterium is die groepering van woorde in 'n sin. Maar omdat dit wat met die term "sin" bedoel word, gewoonlik nie linguisties bepaald is nie, doen ons beter om 'n ander term vir ons basiese eenheid te gebruik. Met "sin" word gewoonlik bedoel ' $n$ eenheid wat in geskrewe taaluitinge tussen punktuasietekens staan of wat in gesproke taaluitinge deur ' $n$ intonasiepatroon uitgedruk word. Die linguistiese verskynsel "sin" val nie altyd hiermee saam nie, en daarom praat ons liewer van kola wanneer ons taaluitinge linguisties wil afbaken. 'n Kolon is baie maklik om te snap (in teorie altans!). Die minimumdefinisie daarvan is bloot 'n konstruksie wat nie self lid is van 'n konstruksie nie. (Vgl A W de Groot, Inleiding tot de algemene taalwetenschap, Groningen 1964, pp 59-60). ' $n$ Bietjie meer tegnies sou ons dit kon weergee met die formule $N+V$, dit wil sê een naamwoordstuk en een werkwoordstuk. Indien ons in 'n stuk taal 'n naamwoordstuk en 'n werkwoordstuk teenkom wat nie herlei kan word as behorende tot ' $n$ ander naamwoordstuk en werkwoordstuk nie, dan is dit'n afsonderlike kolon. Byvoorbeeld:

Die man het gekom om dood te maak

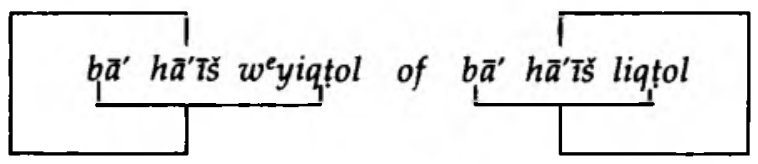

Dit is een kolon omciat daar slegs een konstruksie is, dit wil sê waar alles teruggevoer kan word tot een $\mathrm{N}+\mathrm{V}$. Die $\mathrm{N}$ is hier $h \bar{a} \bar{a}^{\prime} \bar{s}$ en die $\mathrm{V}$ is $b \bar{a}^{\prime}$ liqtol of, in die tweede geval, $b \bar{a}^{\prime} w^{\prime}$ yiqtol. $b \bar{a}^{\prime}$ liqtol en $b \bar{a}^{\prime} w^{e} y i q-$ tol verteenwoordig twee moontlikhede om in Hebreeus die finale konstruksie uit te druk, naamlik $l^{e}$ plus infinitief en $w^{e}$ plus 'n imperfektiese vorm. So is liqtol en $w^{e}$ yiqtol uitbreidings op $b \bar{a}^{\prime}$ en derhalwe tuis te bring onder een werkwoordstuk. Aan die ander kant:

Die man het gekom en hy het doodgemaak

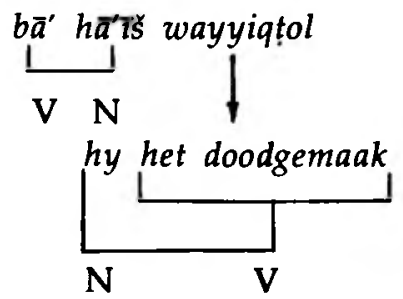


Dit is twee kola omdat beide ' $n$ afsonderlike naamwoordstuk en werkwoordstuk het wat nie linguistiese uitbreidings binne een konstruksie verteenwoordig nie, maar afsonderlike konstruksies in eie reg is. (yiqtol se naamwoordstuk word as die derde-persoonselement in een morfologiese vorm met die werkwoordstuk vervat, soos in die skema hierbo aangedui.)

Ons het dit nou in Hebreeus tegelyk makliker en moeiliker as in Grieks. In Hebreeus kom daar ' $n$ parataktiese neiging in die sinsbou voor en in Grieks 'n hipotaktiese. Dit wil sê Hebreeus neig meer tot neweskikking as tot onderskikking, terwyl dit omgekeerd is in Grieks. Dit gee ons in Hebreeus wel minder vorme om te leer as Grieks, maar'n groter verantwoordelikheid tot noukeurigheid by die afmerk van ons kola. Byvoorbeeld:
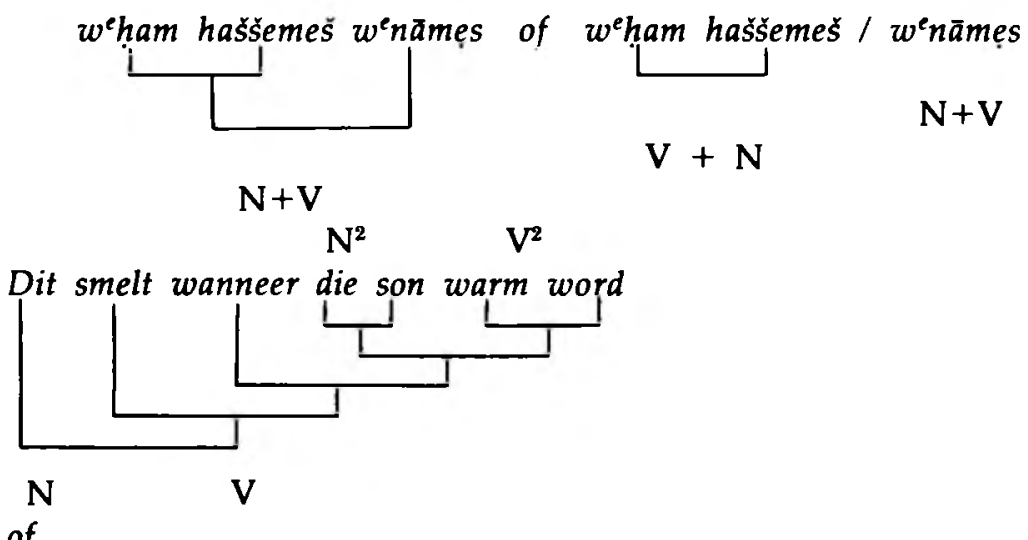

of

Die son word warm en dit smelt

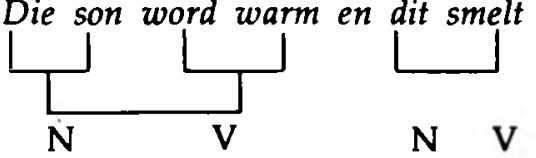

Vanweë die parataktiese neiging in Hebreeus word dieselfde neweskikkende konsekutiewe perfektum gebruik vir twee afsonderlike konstruksies èn vir een konstruksie waar die werkwoordstuk "smelt" uitgebrei word deur die temporele bepaling. Hierdie verskynsel word in Hebreeus verder bemoeilik deurdat daar nie soveel duidelike morfologiese onderskeidings is wat die gesig van konstruksies bepaal nie. Hiervoor kan ons weer na die eerste voorbeeld kyk:

Die man het gekom om dood te maak.

In Grieks is daar 'n bepaalde konstruksie (hina plus subjunktief naas alternatiewe) wat ' $n$ morfologiese middel bied om te kan onderskei: ho anēr èlthen hina apokteinē, teenoor ho anēr êlthen kai apokteinei 
wat die weergawe is van Die man het gekom en hy het doodgemaak. In een geval hina plus subjunktief en in die ander kai plus indikatief. In Hebreeus kan die volgende uitspraak verskillend funksioneer:

$b \bar{a}^{\prime} h \bar{a}^{\prime} i{ }^{\prime} w^{\mathbf{e}}$ yiqtol

Ons kan in $w^{e}$ plus imperfektum òf die finale waw hê òf die alternatief vir die konsekutiewe perfektum. Dus:

Die man het gekom om dood te maak (een kolon)

of

Die man het gekom en hy sal doodmaak (twee kola)

of selfs ' $n$ derde moontlikheid:

Die man het gekom en hy moet doodmaak (twee kola).

Die derde moontlikheid bestaan omdat die jussief in Hebreeus meestal dieselfde morfologiese vorm as die imperfektum het.

Die natuurlike vraag wat nou opkom, is hoe mens vasstel wat is wat wanneer daar sulke moontlikhede naas mekaar bestaan. Hier geld die prinsipe wat ek vroeër genoem het, naamlik dat ons, soos ons stappe vorentoe neem, die afgehandelde werk herkontroleer. Mens moet dus die verskillende moontlikhede afsonderlik oorweeg. Dan sal die verdere struktuurpatroon van die betrokke teks daartoe bydra dat ons kan kies watter een van die verskillende moontlikhede korrek is. Indien daar geen strukturele aanduidings gevind kan word dat ons byvoorbeeld een kolon het in $b \bar{a}^{\prime} h \bar{a}^{\prime} \bar{i} w^{\mathbf{c}}$ yiqtol nie, moet ons twee afsonderlike kola afmerk. Wanneer die man byvoorbeeld by sy aankoms verklaar: $E k$ is gestuur om dood te maak (šullahtī liqtol), word 'n duidelike doelkonstruksie gebruik. Dan kan ons kies vir die wawfinale en een kolon afmerk. In 'n konteks waar die man byvoorbeeld met vreedsame bedoelings gekom het maar daarna beledig is, sal ons hier met twee kola te doen hê. Dan sal die verdere struktuurverhoudings aandui dat hierdie twee kola buitendien met mekaar kombineer. Byvoorbeeld:

1. $b \bar{a}^{\prime} h \bar{a}^{\prime} \bar{\imath} \check{S}$

2. weyiqtol

Die twee kola word deur middel van $w^{e}$ met mekaar gekombineer en so vorm hulle buitendien 'n eenheid - nou alleen op 'n breër vlak, naamlik as kolonverbinding en nie as enkele kolon nie.

\section{B. Die stige}

Dit bring ons by 'n volgende saak, naamlik die onderskeid tussen prosatekste en poëtiese tekste. Die hele doel van ons struktuuranalise is om vas te stel hoe 'n outeur sy teks opgebou het. Die enigste formele kriterium wat ons by prosatekste het, is die linguistiese verskynsels $\mathrm{S} \rightarrow \mathrm{N}+\mathrm{V}$, die kolon, waarvan die taalkunde ons geleer het dat 
dit ten grondslag lê aan enige sinvolle taalgebruik. Maar by poësie kom daar' $n$ tweede gesigspunt na vore. Poësie is ook sinvolle taalgebruik en kan so ook in kola ingedeel word. Maar wanneer'n digter sy gedig opbou (struktureer) gebruik hy nie noodwendig die kolon as sy basiese bousteen nie. Daarvoor gebruik hy die stige of versreël (of vers, maar nie in die sin van die ongelukkig ingeburgerde "vers" as aanduiding van 'n genommerde stukkie van die Bybel nie).

So 'n stige val nie noodwendig saam met 'n kolon nie. Een stige mag meer as een kolon bevat, of een kolon mag oor meer as een stige strek. Byvoorbeeld:
1
$\begin{array}{lll}2 & 3 & 1\end{array}$
23

rām ${ }^{c}$ al kol qōyim yhwh ${ }^{c}$ al haššămayim $k^{e} b \bar{o} d \bar{o}$ (Ps 113:4)

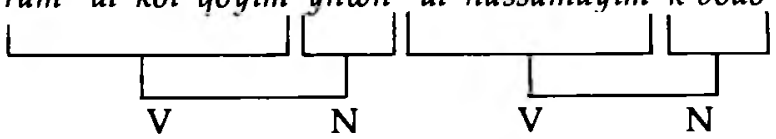

Yahweh is verhewe bo alle nasies. Sy eer is bo-oor die hemele.

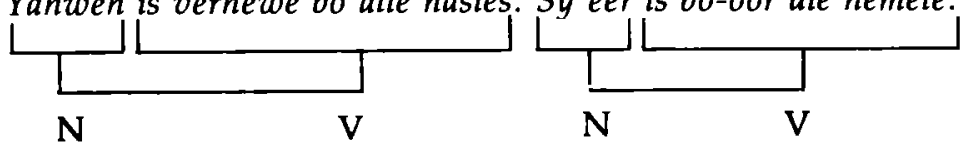

Hier het ons een stige, maar twee verskillende kola met elk ' $n N+V$. Verder:
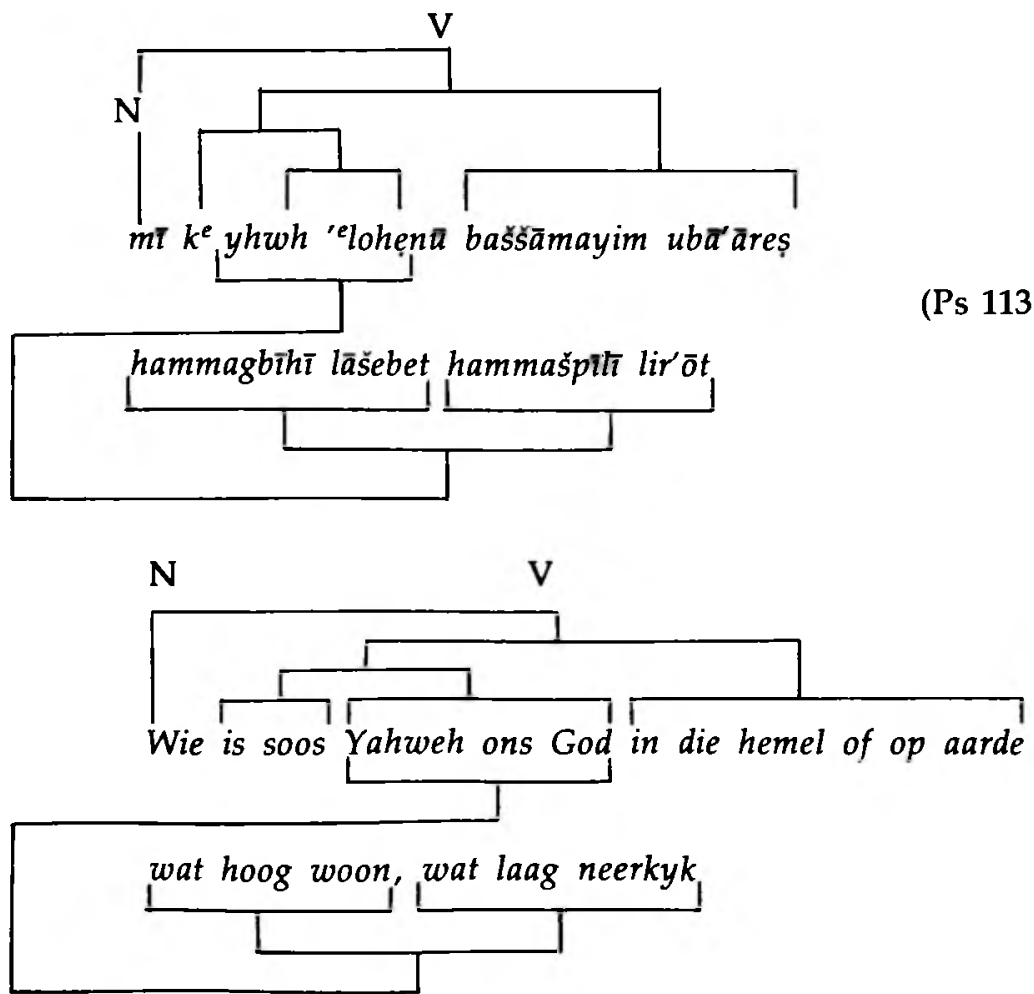
Hier het ons twee stiges, maar een kolon met 'n enkele $N+V$.

Dit beteken nou die dat die kolonprinsipe verval wanneer ons met poësie te doen het nie (poësie is immers ook sinvolle taalgebruik!). Daarom kan mens ' $n$ gedig inderdaad analiseer deur van koloneenhede uit te gaan. Maar omdat die digter gebruik gemaak het van stiges as die boustene vir sy gedig, bied hy ons as 't ware sy eie eenheid aan sodat ons daarlangs die pad wat hy by die bou van sy gedig gevolg het, kan nastap. In die praktyk beteken dit dat' $n$ analise volgens stiges meer nuanses sal oplewer as ' $n$ analise volgens kola alleen. Maar ' $n$ kolon-analise en 'n stige-analise sal mekaar nie weerspreek nie. Soos ons die bou van die gedig natrek, sal ons 'n punt bereik waar die kolon-analise en die stige-analise met mekaar ooreenval.

Die voorbeeld van Psalm 113:4-6 sal dit illustreer. 'n Kolon-analise van dié gedeelte lyk soos volg:

1. ram 'al kol gōyim yhwh

2. 'al haššāmayim $k^{e} b \bar{o} d \bar{o}$

3. mī $k^{e} y h w h{ }^{\prime}$ lohẹnū bāššāmayim ūbā'āreș hammagbīhī lāšebet hammašpīt lir' ōt

Die twee kola van rām tot $k^{e} b \bar{o} d \bar{o}$ val saam as 'n kombinasie, en hierdie kombinasie verbind weer met die enkele kolon van $m \bar{l}$ tot by $l i$ $r$ 'ot. 'n Stige-analise lyk nou só:

1. rām ${ }^{1} c_{a l} k o l$ gōyim ${ }^{2} y h w h^{3} c_{a l}^{1}$ haššămayim ${ }^{2} k^{e} b \bar{o} d \bar{o}^{3}$

2. $m \bar{l}^{1} k^{e} y h w h^{2}{ }^{\prime} e l o h e ̣ n \bar{u}^{3}$ baššămayim ${ }^{1} \bar{u} b \bar{a}^{\prime} a \bar{r} e s^{2}$

3. hammagbīh $\bar{t}^{1}$ lāšebet $^{2}$ hammašpititi ${ }^{1}$ lir $^{\prime} t^{2}$

Weer kry ons 'n eenheid van rām tot $k^{e} b \bar{o} d \bar{o}$, en dié verbind weer met die kombinasie van twee stiges van $m \bar{\imath}$ tot lir'ōt. In die stige-analise sien ons egter meer as in die kolon-analise: Eerstens val die strukturele eenhede saam met die metriese eenhede. Tweedens sal ons by nadere toesien opmerk dat die twee laaste stiges die eerste een kwalifiseer - wat weer presies ooreenkom met wat in die res van die gedig gebeur; telkens word een stige deur twee daaropvolgende stiges uitgebou of gekwalifiseer. Hierdie belangrike gegewens kan nie bekom word deur die inligting wat'n kolon-analise ons alleen verskaf nie.

Om hierdie redes reken ek dat die natuurlikste werkswyse by die struktuuranalise van $\mathrm{Ou}$-Testamentiese poësie uitgaan van die eenheid wat die digter self gebruik het. Ons wil immers niks anders vasstel as hoe hy sy gedig opgebou het nie. Daarvoor kan ons dan 'n bykomende kontroletoets gebruik, naamlik die kolon-analise.

As ons dan by poëtiese tekste van stiges moet uitgaan, moet ons ook weet hoe om 'n stige af te merk. ' $n$ Stige is nie 'n linguistiese eenheid soos 'n kolon nie, maar'n stilistiese eenheid. In Hebreeuse 
poësie (moderne Hebreeus uitgesluit) word 'n stige metries bepaal. Die Hebreeuse metrum werk met klemtoonheffings (dus ' $n$ aksentuerende metrum) en nie met lettergreephoeveelhede en -lengte nie (dus nie 'n kwantiterende metrum soos in Griekse of Latynse poësie nie). Sulke klemtoonheffings kombineer met mekaar sodat ons ' $n$ aantal tipiese heffingkombinasies $k r y$ ('n heffingskombinasie $=$ ' $n$ versvoet). Hierdie kombinasies bots egter nooit met die sintaktiese patroon in ' $n$ stige nie. As een stige twee kola bevat, sal daar twee versvoete wees. Byvoorbeeld:

hallelū' 'abdệ' yhwh' hall'lü' 'et šẹm' yhwh'

Hier vind ons twee kola. Elkeen bestaan uit 'n versvoet van drie klemtoonheffings (deur die strepies aangedui, terwyl ek hierbo by verse 4-6 syfers gebruik het), sodat ons 'n 3+3-vers kry. As 'n stige egter nie meer as een kolon bevat nie, sal elke versvoet 'n sintakties sinvolle woordgroepering omvat. Byvoorbeeld:

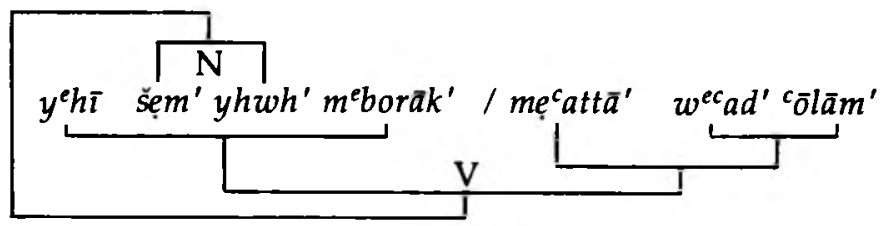

Hier kom ook twee versvoete van drie klemtoonheffings elk voor. $m e^{c} a t t \bar{a} w^{e c} a d{ }^{c} \bar{o} l \bar{a} m$ is wel 'n uitbreiding op $y^{e} h \bar{\imath} m^{e} b o r a \bar{k}$, maar is nog 'n sinvolle woordgroep (in hierdie geval 'n voorsetselstuk), en die eerste versvoet ( $y^{e} h \bar{l}$ šẹ $\left.y h w h m^{e} b o r a \bar{k}\right)$ kan nog alleen staan.

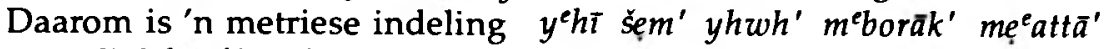
$/ w^{e c} a d^{\prime}$ 'ō̄ām' $(4+2)$ onmoontlik.

Daar is verskeie tipiese heffingskombinasies in die Hebreeuse poësie:

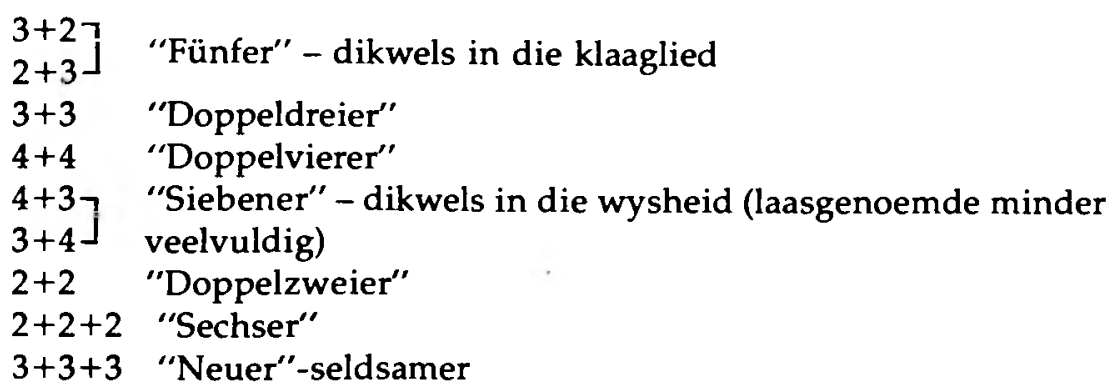

Soms kom daar ook enkelvoetige stiges voor (alleen 3 ) - byvoorbeeld wanneer die direkte rede ingelei word. In besondere gevalle kom daar onortodokse klemtoonkombinasies voor. Dit kan veral in die boek Prediker gesien word, waar 'n protesterende, onortodokse inhoud gekombineer word met 'n protesterende, onortodokse ritmiese vorm (vergelyk Breyten Breytenbach se vorm en inhoud met dié van Totius!). 
Dikwels het partikels nie klemtoon nie, en daar word gestrewe teen die beklemtoning van lettergrepe wat onmiddellik op mekaar volg (slegs 'n paar sulke gevalle kom in besondere omstandighede voor).

\section{Struktuurmerkers}

Wanneer ons ons perikoop nou in kola of stiges gedeel het, moet ons die verbindings aandui. Daarvoor kan ons 'n sisteem van lyne gebruik. Daar is verskeie struktuurmerkers wat as kriteria dien om vas te stel wat hoort by wat. Die belangrikste merkers is die volgende:

Voegwoorde (soos $w^{e}$ en $k \tau$ ) is verbinders na vore. So ook pronominale opname deur suffikse, voornaamwoorde en persoonsvorme in die werkwoord vervat (byvoorbeeld wanneer "hy" of "sy" in een kolon terugslaan op 'n selfstandige naamwoord in 'n vorige kolon). Verder dien imperatiewe en vrae dikwels as verbinders met wat volg. So ook die opname van 'n nominatief as akkusatief of datief in 'n volgende kolon (of, natuurlik, stige). Wanneer ons met stiges werk, kan die kontrolerende kolonindeling ook toon wat moet kombineer (wanneer twee stiges een kolon uitmaak, is dit 'n merker dat dié twee stiges verbind). Wanneer die subjek wissel sonder dat daar 'n pronominale opname plaasvind, wanneer dus terugverwysings deur middel van voornaamwoordelike elemente ophou, is dit 'n teken dat hier 'n skeiding in die teks voorkom. Die herhaling van dieselfde element beteken ook dat hulle met mekaar in verbinding staan. Daar kan ook van semantiese kriteria gebruik gemaak word om vas te stel hoe struktuur daar uitsien. Gestel twee stiges (vier hemistiges) lui: Mooi is die dame, lelik is die man; afskuwelik die heer, pragtig die dame. Dan is dit duidelik 'n chiasme (ABBA), en dit dui daarop dat die twee stiges verbind. Nogtans het ons ons nie met die betekenis besig gehou in dié sin dat ons die seggingskrag van die stiges in hul konteks gaan uitwerk het nie (dit volg eers in 'n latere stap).

Op hierdie wyse stel ons vas hoe die verskillende inhoudsmomente in relasie tot mekaar staan. Dit bied die dissiplinerende raamwerk waarbinne ons die betekenis van die inhoud kan ondersoek.

IV EXODUS 22:20-26

\section{A. Afgrensing}

Die afgrensing van hierdie perikoop is op die oog af heel eenvoudig. In die voorafgaande gedeelte vind ons ' $n$ aantal wette oor eiendom, oor buite-egtelike geslagsgemeenskap met 'n ongetroude meisie en oor towerhekse. Vanaf vs. 27 kom daar wette voor oor wat aan Yah- 
weh verskuldig is (opbrengste, eersgeborenes van mense, eersgeborenes van diere) en oor die eet van verskeurde vleis. Omraam deur hierdie verskeidenheid van wetsbepalings kom daar nou 'n gedeelte voor wat tematies ' $n$ eenheid is. Dit gaan naamlik om die reëling van die posisie van sosio-ekonomiese swakkelinge. Dus het ons'n prima facie argument dat hierdie passasie ' $n$ perikoop uitmaak. Maar hierdie afgrensing is alleen op tematiese gronde gedoen. Daar is geen tipiese slotformules of inleidingsformules wat die grense tussen die verskillende eenhede aandui nie. Dit is ' $n$ veel voorkomende verskynsel in die wetlike literatuur van die Ou Testament (hoewel dit ook elders voorkom, byvoorbeeld in Spr 10vv.). Derhalwe moet ons in sulke gevalle des te swaarder steun op ons volgende stap, naamlik die struktuuranalise. Ons moet dus kontroleer of daar formele gegewens voorkom wat hierdie afgrensing bevestig of weerspreek.

\section{B. Struktuur}

1. $w^{e}$ gẹ $l o^{\prime}$ tōnē

2. $w^{e}$ lo tilhāṣennū

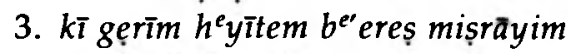

4. $k \bar{T}$ 'almānā $w^{e}$ yātōm lo' $t^{e c}$ annū un

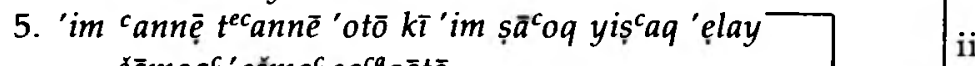
šāmoa $a^{c}$ 'ešma $a^{c}$ șa $^{c a} q \bar{a} t \overline{t o}$

$w^{e} h \bar{a} r \bar{a}{ }^{\prime} a p p \bar{\imath}$ w'hāragtT'etkem behāreb $w^{e} h \bar{a} y \bar{u} n^{e}$ šẹkem 'almānōt ūbenẹkem y $y^{e}$ tomìm

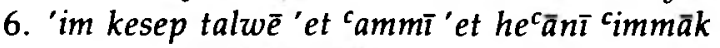
lo' tihyē lō $k^{e}$ noše

7. lo' teŝ̀ìmūn 'ầlāw nešek

8. 'im hâabol tahbol śimlat rẹ̣ceka $c_{a d} b \bar{o}^{\prime}$ haššemeš teš̉bennū $\overline{l o}$

9. $k \bar{i} h \vec{\imath} k^{e} s \bar{u} t \bar{o} l^{e} b a d d \bar{h}$

10. $h \vec{r}$ śsimlātō lec orō

11. bammē yiškāb

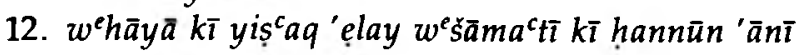

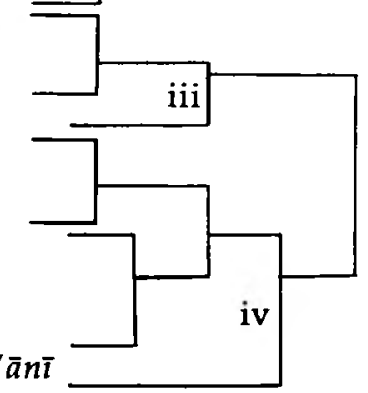

Kola 1 en 2 word aan mekaar verbind deur die voegwoord $w^{\ell}$ en deur die pronominale opname van ger in die derde persoon manlik enkelvoud suffiks. Dan verbind die derde kolon aan dié kombinasie deur $k \bar{\imath}$ en deur die opname van gẹr as gẹīm.

Kola 4 en 5 word verbind deur die pronominale opname van yătōm in die derde persoon manlik enkelvoud suffiks. Die feit dat 'alm̄aña vroulik is en nie in die suffiks opgeneem word nie, word verklaar deur die feit dat die manlik in Hebreeus dikwels in sulke (en soortgelyke) gevalle die vroulik oorheers. 
Kola 6 en 7 word ook verbind vanweë hierdie struktuurmerker (opname van ${ }^{\bar{a}} \bar{a} \bar{\imath}$ in die suffiks van ${ }^{\bar{a}} \bar{a} l \bar{a} w$ ).

Kola 9, 10 en 11 word deur dieselfde beginsel aan 8 verbind (die manlike suffiks by $t^{\iota} \operatorname{sitbenn}_{\bar{u}}$ en die pronomen $h \bar{u}^{\prime}$ wat śimlā opneem, terwyl dié as manlik geneem word, maar in die Masoretiese vokalisasie van $h w^{\prime}$ as vroulik geneem word - vandaar die $k^{e} t i b$ en $\left.q^{e} r e ̨\right)$, terwyl die derde persoon manlik enkelvoud in yiškab die pronominale opname van rẹac is. 9, 10 en 11 word ook deur die motiverende $k \bar{\imath}$ aan die voorafgaande kolon gekoppel. Kolon 12 word deur die voegwoord $w^{e}$ en deur die derde persoon manlik enkelvoud in yiş ${ }^{c} a q$ aan die voorafgaande kombinasie verbind. Die $w^{e}$ toon ook aan dat 12 nie deel uitmaak van die motivering nie, want dit lei die sogenaamde toekomsformule in.

\section{Inhoud}

In die eerste seksie vind ons twee gebooie van die sogenaamde apodiktiese soort, dit wil sê waar 'n kategoriese voorskrif gegee word. Hulle sê dat die gẹr nie verdruk mag word nie. ynh en lhs is werkwoorde wat semanties oorvleuel en dus hier dieselfde beteken: Onregmatige druk uitoefen (druk, onregmatig, teenoor swakkelinge, op sosio-ekonomiese gebied). Die gẹr is 'n vreemdeling (behoort nie tot die volk nie, het geen eiendomsreg nie). Geen sosio-ekonomiese druk mag dus uitgeoefen word ( $l \bar{\sigma}^{\prime}$ plus imperfektum is ' $n$ volstrekte verbod) op diegene wat geen eiendomsreg het nie. Maar nou kom daar ' $n$ motiverende klousule by (kolon 3). Diegene aan wie die voorskrif gegee word, was self vreemdelinge in Egipte. Die motivering is dus histories-psigologies. Hulle weet hoe dit voel en daarom kan hulle medelye hê met diegene wat nou dieselfde posisie beklee as wat hulle in Egipte beklee het. (In Exodus 23:9 kom dieselfde gebod en motivering voor, waar daar nog bygesê word dat hulle die nepeš van die vreemdeling ken.)

Nou word hier 'n hele tradisie opgeroep. Deurdat gesê word Israel was (perfektum) vreemdelinge in Egipte, word die hele exodustradisie as motiveringsbasis gebruik: Israel is verlos uit daardie sosioekonomiese verdrukking en mag daarom nooit pleeg waaronder hulle gely het nie. Hierdie motivering is daarom besonder belangrik: Daar word ' $n$ teologiese basis vir die sosio-ekonomiese reëling gegee. Hulle is verlos deur Yahweh, en daarom verwag Yahweh dieselfde gesindheid van hulle teenoor gerim as wat $\mathrm{Hy}$ in soortgelyke omstandighede teenoor hulle bewys het. So word die wetlike reëling tot 'n teologies onderboude respons op Yahweh se optrede in die verlede. En dit word ook verinnerlik tot 'n gesindheidsaak - nie alleen ' $n$ uiterlike wetsonderhouding nie, maar' $n$ gesindheid wat in die praktyk gestalte kry. 
Dan kom seksie (ii). Hier word die weduwee en die wees genoem. Ook hulle mag nie onder sosio-ekonomiese druk kom nie. Die weduwee is ' $n$ vrou sonder ' $n$ man wat haar kan versorg en haar reg kan handhaaf. Die wees is ' $n$ kind sonder vader wat hom kan versorg of sy reg kan handhaaf. Hulle word telkens in die Ou Testament met die gẹr verbind en geld as die drie tipiese kategorieë van sosio-ekonomiese weerloses. Hierdie apodiktiese verbod word ook onderbou. Dié keer verbind dit met 'n lang kondisionele kolon. As hulle verdruk word en tot Yahweh roep, sal Hy hulle sekerlik hoor. Die eerste persoon enkelvoud is hier Yahweh omdat daar in die komposisionele konteks van die sogenaamde Bondsboek waarin ons perikoop voorkom, van Hom sprake is (die hele komposisie word aangebied as sy voorskrifte aan Israel). Hy dreig met sy toorn wat gemanifesteer sal word in (a) militêre geweld teen sy eie volk (hereb is dikwels 'n metafoor vir militêre geweld) en (b) die konsekwensie van die omkeer van magsverhoudinge (die verdrukkers se vrouens word weduwees en hul kinders wese - dus 'n ingrype van Yahweh wat gebaseer is op die talionis-prinsipe). Die onderbou vir die gebod is hier dus die dreiging van Gods straffende ingrype.

In beide seksies kies God kant vir die swakkes teen die sterkes. Maar dit geskied nie omdat hulle respektiewelik swak en sterk is nie. Hy gryp alleen teen die sterkes in (seksie ii) wanneer hulle hul mag on regverdiglik misbruik.

In seksie (iii) kom 'n verwante aangeleentheid ter sprake. Hier gaan dit om die ${ }^{c} a n \bar{\imath}$ van die volk. Dit wil sê om die arme wat aan Israel behoort. Hulle moet renteloos te lene kry. Hier word nie 'n motiverende onderbou gegee nie. Maar daar is wel 'n verband tussen seksies (iii) en (iv). Die arme wat aan Gods volk behoort (kolon 6), word hier deur rẹac, naaste, opgeneem. As hy sekuriteit moet gee, kom daar bepaalde voorskrifte. $h b l$ is die invorder van 'n pand, as sekuriteit, teen 'n lening. Dit gaan om 'n arme wat alleen sy kleed kan gee en wat alleen een kleed het, soos kolon 9 en die retoriese vraag in kolon 11 toon. Die wet is kasuïsties geformuleer. ' $n$ Pand mag wel geneem word, maar moet dieselfde dag teruggegee word. Daardeur word die neem van 'n pand effektief ontkragtig. Maar die motivering is veral in ' $n$ ander opsig merkwaardig: Die retoriese vraag in 11 sê dat die arme iets moet hê om in te slaap. Dit wil sê dit is ' $n$ humanitêre motivering. Die gedeelte sluit met nog 'n verwysing na Yahweh wat sal hoor as so 'n arme tot Hom roep, want Hy is genadig. Sy genade word hier dus spesifiek op die armes betrek. In die konteks van die tweede seksie het hierdie verwysing dus weer 'n dreigende funksie.

Samevattend kan gesê word dat hierdie sosio-ekonomiese bepalings op drie maniere gemotiveer word: Heilshistories (soos Gemser dit noem) of liewer histories-psigologies, vrees vir Gods straffende ingrype, en humanitêr. 


\section{Tradisie-historiese perspektief}

Ons vind soortgelyke waardering vir die beskerming van die wese en weduwees teen magtiges en rykes in ander oudoosterse wetskodekse. Hiervoor kan byvoorbeeld vergelyk word die proloog van die Sumeriese kode van Ur-Nammu. Maar die verskil lê in die motiverende onderbou wat hier gegee word. Daarin lê die spesifiek Israelitiese element. Daarom kan ons sê dat, wat ookal die oorsprong van dergelike bepalings was, die spesifiek Israelitiese karakter in die motiveringsklousules lê. Hier lê dan ook die teologiese kwaliteit van die wetgewing verskans.

\section{E. Komposisie}

Soos vroeër vermeld, wys die breë komposisionele verband van die Bondsboek uit dat ons hier te doen het met die woorde van Yahweh.

\section{F. Prediking}

As dit nou Gods woord is, hou dit vir ons veel in. Christus is ook hiervan die vervuller, sodat die wet nie afgeskaf word nie, maar 'n nuwe funksie bekom. Dit reël nou die dankbaarheidslewe van 'n gelowige.

Gods verlossing is die basis vir ons sosio-ekonomiese geregtigheid. Hy verlang op dié terrein van ons dieselfde mededoë teenoor ons medemense as wat Hy teenoor ons betoon het. So word sosioekonomiese geregtigheid 'n dankbaarheidsplig (soos ook vir Israel wat uit Egipte verlos is). So word dié saak ook verinnerlik: Dit is 'n kwessie van meegevoel. Hier kan ons perikoop goed met die Afrikaner wat sy geskiedenis ken, kommunikeer. Die Afrikaner weet wat dit is om in die samelewing veronreg te word. Sy verwysingsraamwerk het heelwat in gemeen met dié van die ou Israeliet wat die geskiedenis van die exodus so goed geken het. Ons sal mededoë moet leer.

Gods opdrag oor hierdie saak is ook voorsien van 'n dreiging: Die omkeer van rolle deur militêre geweld. Hoe goed dit vandag met ons behoort te kommunikeer, hoef nie eers genoem te word nie. Gods eie volk kan van sy eie hand so' $n$ ingrype oorkom wanneer hy na binne nie die sosio-ekonomiese geregtigheid beoefen nie.

En God wil 'n humanitêre gesindheid by sy gelowiges hê. Dade wat uit 'n medemenslike mededoë voortkom. Ook dit het vandag aktualiteit: Ons kan nie so maklik mededoë en medemenslikheid as "humanisme" en "liberalisme" afmaak nie. 


\section{A. Afgrensing}

Prediker 1:12-2:26 is ' $n$ beskrywing van 'n wysheidsproefneming wat Qohelet gemaak het. Dit is in die styl van die eerste persoon enkelvoud aangebied. In 3:10 begin daar weer' $n$ eerste-persoon-styl. Dit is een aanduiding dat ons in die stuk tussenin ' $n$ afsonderlike perikoop het. Verder begin 3:10 ook met' $n$ waarnemingsformule wat ná die voorafgaande gedeelte (soos meermale) die inleiding van 'n nuwe stuk merk. Dit bevestig die afgrensing van die einde van die perikoop 3:1-9. Die begin word weer bevestig deur die feit dat daar 'n tematiese wisseling in vers 1 plaasvind (die motief van tyd word hier ingevoer ná die wysheidsproef van die vorige gedeelte). So sit ons met een perikoop in 3:1-9. Hierdie afgrensing sal nou bevestig word, dink ek, deur die volgende stap in ons metode, naamlik die struktuuranalise.

\section{B. Die struktuur}

Die hele gedeelte is poësie. Dit kan al dadelik gesien word in die drukwyse van die Biblia Hebraica ${ }^{3}$ en die Biblia Hebraica Stuttgartensia. Elke stige is op 'n aparte reël gedruk. Nou is ons perikoop linguisties ook besonder eenvoudig. Elke versreël of stige bestaan uit twee kola of sinne, behalwe die heel laaste een wat net uit een kolon bestaan, naamlik die retoriese vraag in vers 9 . Verder is daar' $n$ ooglopende simmetrie in die stuk deurdat elke kolon 'n sogenaamde nominale $\sin$ is en deurdat elkeen (behalwe die eerste en die laaste) presies eenders gestruktureer is: ' $n$ Tyd vir $x$ en ' $n$ tyd vir $y$ - telkens 'ẹt gevolg deur infinitivus constructus, in die meeste gevalle met $l^{e}$ wat dikwels met die infinitivus constructus in Hebreeus voorkom. Alleen in vers $8 b$ (die laaste stige oor die $e^{e} t$ ) kom daar twee selfstandige naamwoorde voor in dié posisie waar daar elders die infinitivus constructus staan.

Hoe gaan ons nou die struktuur hiervan bepaal? As uitwendige struktuurmerkers het ons alleen die voegwoord $w^{e}$ wat die twee vershelftes van elke versreël met mekaar verbind. Maar niemand sal sê dat die stiges hier ' $n$ klomp losstaande uitsprake is nie. Dit is te duidelik dat die naamwoordstuk in elkeen (behalwe die laaste) van hierdie kola presies dieselfde is - keer op keer ${ }^{c} e t$, en in vs. la die sinonieme Arameïsme $z^{e} m \bar{a} n$. Daar kan ook nie blote toeval skuil agter die feit dat die kola keer op keer dieselfde linguistiese bou het nie. Daarom moet hulle met mekaar te doen hê en moet ons na 'n ander manier soek om vas stel wat die strukturele verhoudings tussen die verskillende kola en stiges is.

En hier kom ons na my mening by 'n baie belangrike punt. As ons na die woorde in elke kolon kyk, dan merk ons op dat die woorde in 
een vershelfte telkens die antitese is van die woorde in die een langs hom: Gebore word :: doodmaak, plant :: uitruk, doodmaak :: genees, afbreek :: bou. En as ons na dié verhouding in die verskillende stiges kyk, vind ons dat elke stigepaar (die sogenaamde verse in die Bybel) nie antiteties nie, maar parallel aan mekaar loop (wat in die tradisionele terminologie van die Hebreeuse poëtiese stilistiek die sinonieme parallelisme genoem word). En hierdie verskynsel word nou so fyn uitgebou dat dit onmoontlik toevallig kan wees. Inteendeel, dit is so ragfyn uitgewerk dat ons dié perikoop een van die fynstes in die hele Bybel kan noem. Die belangrike waarneming wat ons hier gemaak het, is dat die bou of oppervlaktestruktuur van 'n perikoop ook met semantiese vrae te doen het. Ons vind in dié perikoop alleen uit wat waarmee verbind as ons die semantiek van die woorde bekyk. Semantiese of betekeniskwessies het dus nie alléén met die dieptestruktuur van 'n perikoop te doen nie, maar kan ook 'n rol speel in die bepaling van die verbindinge in die oppervlaktestruktuur. Dit wil egter nog nie sê dat ons by die oppervlaktestruktuur kan ophou en meen dat ons nou alles vasgestel het oor hoe die betekenis van sulke woorde in die geheel van die gedig of perikoop funksioneer nie.

Hierdie hele opset wil ek nou skematies illustreer. Ek gee nie die hele gedig weer nie, maar om ekonomiese oorwegings skryf ek net neer wat nodig is vir die aanduiding van die bou van ons perikoop.

1. Vir alles is daar 'n tyd, ' $n$ geleentheid vir elke ding

2. i ii

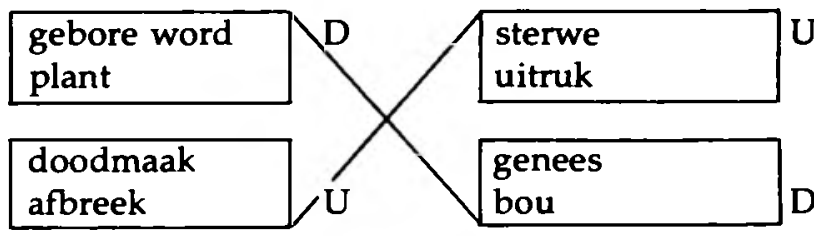

D Chiasme

3. iii iv

4. $\mathrm{i}$ ii

\begin{tabular}{|l|}
\hline $\begin{array}{l}\text { huil } \\
\text { klaag }\end{array}$ \\
\hline
\end{tabular}

5. iii iv
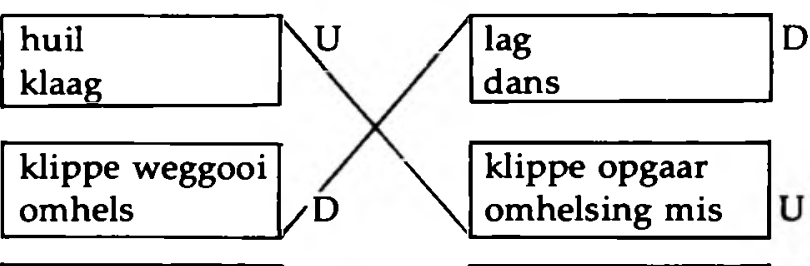

(oktaaf)

6. $\mathrm{i}$ ii

7. iii iv

\begin{tabular}{l|}
\hline soek \\
bewaar
\end{tabular}

8. i

\begin{tabular}{|l|l|l}
\hline $\begin{array}{l}\text { skeur } \\
\text { swyg }\end{array}$ & $\begin{array}{l}\text { vaswerk } \\
\text { spreek }\end{array}$ \\
\hline
\end{tabular}

Chiasme D (sestet)

$$
\begin{aligned}
& \text { liefhê } \\
& \text { oorlog }
\end{aligned}
$$
haat vrede 


\section{Van watter voordeel is die werker dan as hy swoeg?}

As ons nou nog 'n bietjie nader toesien, merk ons op dat hier twee groot pole verteenwoordig is. Aan die een kant vind ons woorde wat met lewe, konservering en blydskap te doen het, en aan die ander kant woorde wat met dood, destruksie en smart te doen het. As ons nou hiervoor respektiewelik die simbole $D$ en $U$ gebruik, kom daar nog iets merkwaardigs uit die verf. Die chiastiese kwatryne is ook ingebou in groter chiasmes. Die eerste twee kwatryne vorm 'n chiastiese eenheid, en kan daarom 'n oktaaf genoem word:

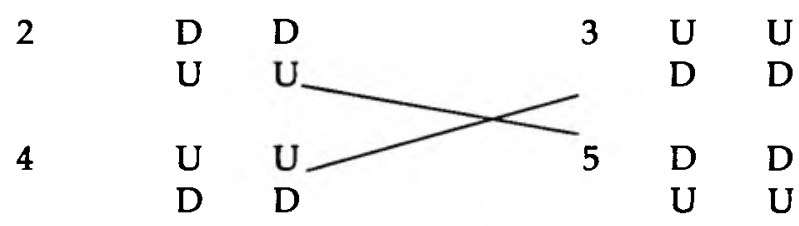

Eers 'n kwatryn wat met $D$ begin, dan een wat met $U$ begin; en dan omgekeerd een wat met $U$ begin, gevolg deur een wat met $D$ begin.

In die laaste ses reëls vind die omgekeerde nou weer plaas. Die kwatryn van vss. 6-7 keer weer terug na dieselfde patroon as die eerste kwatryn wat met $D$ begin, en die chiastiese koeplet van vs. 8 doen dit ook. So word hierdie kwatryn en koeplet weer tot 'n sestet aan mekaar verbind deurdat hulle dieselfde patroon $D U$ vertoon.

Hier het ons dan 'n merkwaardige parallel van die Petrargiese sonnet. In dié sonnet moet daar sestien versreëls wees: Drie kwatryne en 'n koeplet. Die eerste twee kwatryne vorm 'n oktaaf, en die laaste kwatryn vorm saam met die koeplet 'n sestet (waar die koeplet nie mag rym as dit nie ook met die eerste reël van die sestet rym nie terwyl die Shakespeare-sonnet se koeplet onafhanklik van die voorafgaande kwatryn rym).

Alles is dus simmetries opgebou en fyn gestruktureer. Let nou nog op die eerste reël van die hele perikoop. Hy is nie by hierdie skema ingesluit nie, maar bevat ook 'n chiasme:

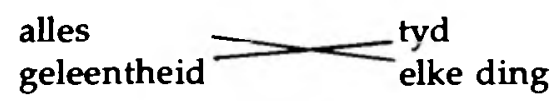

So geld hy as 'n effektiewe inleiding van die chiasmus chiasmorum. Dan bly nog net die retoriese vraag van vs. 9 oor wat die konklusie moet wees.

Nog een opmerking oor die styl. Hier het ons 'n mooi voorbeeld van die figuur van die anafoor, want ${ }^{c} e$ t word 29 keer na mekaar gebruik. 


\section{Die betekenis}

Maar wat beteken die gedig nou? Ons het wel semantiese gegewens gebruik by die vasstelling van wat die bou is, maar dit wat ons teks wil sê, moet nou in die volgende stap vasgestel word:

Die woord "tyd" het verskeie semantiese moontlikhede: (a) tydsverloop, (b) geleentheid. Uit die konteks waar 'ẹt hier bepaal word deur' $n$ reeks gebeurlikhede, kan ons sien dat die woord 'ẹt hier vir laasgenoemde betekenis gebruik word. Dit gaan dus nie om die effek van die tydsverloop op die mens of om die regte tyd waarop mens dit of dat moet doen nie (hoe kan iemand vertel word dat dit nou die regte tyd is om gebore te word of om darem nou 'n slag te sterf?) Dus sê Qohelet dat daar geleenthede is waarby dinge net eenvoudig gebeur.

2. Hy begin by die pole wat die menselewe omspan - lewensaanvang en lewenseinde. Dan presiseer hy dit in die volgende stige (soos in elke stigepaar dwarsdeur die gedig): Plant van die lewensvoedsel teenoor uitroei van die onkruid ('n ekonomiese presisering).

3. Ontneem van die lewe, preservering daarvan. Presisering vind in die volgende stige plaas deur ' $n$ bekende metafoor vir dieselfde saak: Afbreek en bou van die lewe.

4. Ween en lag. Presisering: Dodeklag en vreugdedans.

5. Metafoor van seksuele gemeenskap hê (klippe $=$ manlike saad) en onthouding van seks. Parallel: Omhelsing (dikwels ' $n$ eufemisme vir die geslagsdaad) en onthouding daarvan.

6. Soek en as verlore opgee. Intensivering: Sorguuldig bewaar en wegsmyt.

7. Klere skeur en klere heelmaak. Parallel: Swyg en spreek. Hier kom semiotiese oorwegings in die spel: Klere skeur en swyg vind tydens die routyd as teken van treur plaas. Heelmaak en weer begin praat kan weer ná die routyd plaasvind.

8. Liefhê en haat. Parallel: Oorlog en vrede. Die parallelle konteks toon dat "liefhê" nie hier sy erotiese betekenis het nie, maar generies gebruik word. Die intensivering is dan: Vrede = harmonie, intensiewe haat uitgedruk in vyandelikhede.

Al hierdie lewensgebeurlikhede vind onder die son = in die lewe plaas. Dit is ' $n$ indikatief, nie ' $n$ imperatief nie. Qohelet beskryf wat in die lewe gebeur. Die dinge vind nou eenmaal so plaas. En dan sluit hy met ' $n$ retoriese vraag. Watter wins het die werker dan as hy hom vermoei? Dit is 'n stelling met negatiewe kwaliteit: Die mens het geen voordeel nie. Al sy arbeid en moeite bring hom niks in die sak nie. Die grond hiervoor lê in die konteks van die "sonnet". Alles gebeur eenvoudig in die lewe soos dit gebeur en die mens kan daar met sý werk niks aan doen nie. Hy kan nie deur sy wyse handeling so deur die lewe heen werk dat net die wenslike dinge met hom ge- 
beur nie. Hy is uitgelewer, want die "fallende Zeit" (Zimmerli) val eenvoudig oor hom.

So is die denkpatroon hier 'n polêre spanning:

Pool: Lewe, konservering, blydskap

Teenpool: Dood, prysgawe, smart

Spanning: Uitlewering aan sy lot, hulpeloosheid.

Dit kom ooreen met wat dwarsdeur die boek voorkom: $h^{a} b e ̣ l ~ h a b \bar{t} t m-$ alles is sinloos en vergeefs, die mens kan niks vir homself bereik en verseker nie.

\section{Tradisieperspektief}

Hiermee staan Qohelet in radikale opposisie tot die algemene wysheidstradisie wat gemeen het dat hy die lewe deur sy wysheid, optrede en arbeid kon beheer (dus optimisties). Qohelet protesteer daarteen. Hy is een van die reaksiefigure in die wysheidstroom van die ou Ooste. Daar het 'n verstarring in die wysheid ingetree waarin daar gemeen is dat alles mooi binne 'n sisteempie pas. So het hulle ook die probleme van die werklikheid probeer forseer om in hul skematjie te pas (vergelyk die vriende van Job as voorbeelde hiervan). Qohelet se reaksie is absoluut radikaal. Hy trek 'n streep deur alles.

\section{E. Prediking}

Hier wil ek net aanstip op watter twee vlakke die teologiese draagkrag van hierdie gedeelte na my mening funksioneer - sonder om dit in besonderhede uit te werk.

Wat Qohelet sê, is ook vandag waar. En sy boodskap kry vir ons betekenis in die lig van Christus.

Hy toon hoe hulpeloos die mens sonder Christus is. Alles is 'n lugleegte van sinloosheid en onsekerheid. En as dit nie so was nie, waarvoor was Christus se koms dan nodig?

So waarsku hy ons ook teen verstarde teologiese sisteempies deur sy kritiek op dié skemas wat reken dat hulle alles in 'n rytjie kan sit en al die antwoorde pasklaar het.

In beide hierdie opsigte is die boodskap van Qohelet seker een van die waardevolste besittings wat die kerk vir sy apostolêre taak in die moderne wêreld kan hê.

\section{PSALM 8}

\section{A. Afgrensing}

Die afgrensing van die psalm bied geen probleme nie. Die opskrifte van Pss. 8:1 en 9:1 is twee duidelike grense. Daarby eindig hy met 
dieselfde woorde as wat hy begin, sodat 'n ring voltooi word en 'n geheel gebied word.

\section{B. Tekskritiek}

Tekskrities sit ons egter met 'n probleem in vs. $2 b$. Ons kan nie sin maak van die vorm $t^{e} n \bar{a}$ nie. Nou is dit nie 'n werklike tekskritiese probleem nie, want ons hoef nie aan die konsonanteteks te verander nie. As ons net die pucal se punktuasie lees, kry ons tunnā, dus die werkwoord $t$ hh wat in die picel vir "besing" gebruik word. Hiermee stem ooreen LXX wat epērthē lui. (Dit het ook die nuwe Afrikaanse vertaling nie raakgesien nie - hy bring $t^{e} n \bar{a}$ nog in verband met $n t n$, wat linguisties net nie moontlik is nie.)

\section{Struktuur}

Ons het hier met 'n psalm, dus met poësie te make. Daarom moet ons eers sy stiges indeel voordat ons die bou daarvan kan ondersoek. Dié sien daar soos volg uit:

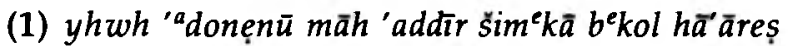

r(2) 'ǎser tunnā hō $d^{e} k a{ }^{c} a l$ haššāmayim mippī ${ }^{c} \bar{o} l^{e} l \bar{l} m w^{e} y \bar{o} n^{e}$ qìm

L(3) yissadtā coz lemacan șōrekekā lehašbìt 'ouyẹb $w^{e}$ mitnaqqẹm

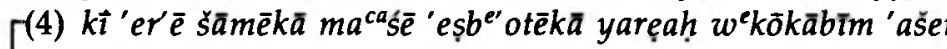

(5) $m \bar{a} h^{\prime e} n \bar{o} \bar{s} k \bar{\imath}$ tizkerennū ūben 'ādām ki tipqedennū

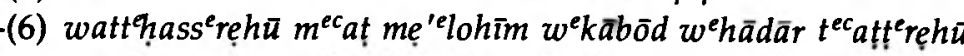

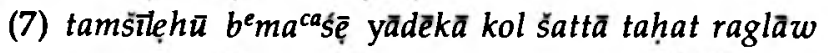

(8) șonē $w \bar{a}^{\prime a}$ lāpīm kullām wegam bah $w^{a}$ ōt śādāy

(9) șippōr šāmayim ūdege hayyām cobęr 'orhot yammīm

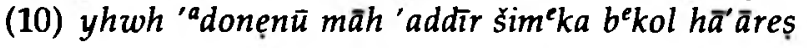

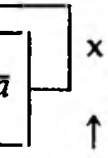

Die stige-indeling in $\mathrm{BH}^{3}$ en $\mathrm{BHS}$ klop nie in vss. 2-3 nie, en is waarskynlik bepaal deur die tekstuele misverstand wat ons pas opgeruim het. Vss. $2 b+3 a$ is een stige van $3+3$ en vss. $3 b+3 c$ nog een van $3+3$ - wat dus ook metries mooi pas.

Die tweede stige begin met 'n voegwoord wat relasie lê met die voorafgaande: "En nou". Maar die eerste en laaste stiges verbind met mekaar omdat hulle identies is. Daarom kan ons sê dat alles daardeur omsluit word. En dus is alles wat tussenin staan, daardeur omsluit - soos dan ook boonop aangedui word deur die tweede stige se verbindingswoord. Stiges 4 en 5 verbind aan mekaar omdat hulle een kolon is. Maar dié eenheid bevat dieselfde pronominale element as stige 3, naamlik tweede persoon manlik enkelvoud en hulle verbind dus ook met mekaar. Dieselfde argument geld vir die verbin- 
ding van 3 en 2 . Verder verbind stige 6 aan die voorafgaande kombinasie vanweë dieselfde pronominale element, vanweë die bykomende derde persoon manlik enkelvoud en vanweë die voegwoord $w^{e}$. Stiges 7-9 vorm ' $n$ eenheid omdat 8 en 9 ' $n$ uitbreiding van 7 se tweede kolon is. En verder verbind dié eenheid ook aan 6 vanweë dieselfde pronominale elemente (gemeenskaplike tweede en derde persoon manlik enkelvoud).

So het ons ' $n$ kettingverbinding tussen die stiges en stigegroepe. Dit word nie weerspreek deur die kolonverbindings nie, want stiges 6 en 7 , wat elk in die middel ' $n$ kolondeling het, se kola verbind ook onmiddellik aan mekaar.

\section{Inhoud}

Wanneer ons nou die inhoud by ons analise betrek, merk ons op dat die gedig in twee dele van vier stiges elk uiteenval (afgesien van die omramende vers). In die eerste helfte vind ons die motief wat ons $h u$ militas (Gemser se woord) kan noem - wat hier met $x$ gesimboliseer word. In die tweede helfte vind ons ' $n$ teengestelde motief $y$, wat ons dignitas kan noem (weer 'n term van Gemser).

Alles word omsluit deur die uitroep oor die heerlikheid van die naam van Yahweh. Dit wil sê die psalm word saamgebind deur lof op sy heerlikheid, want die šẹm yhwh is Hy self.

Net soos daar' $n$ formele verbintenis tussen die inleidende stige en die daaropvolgende stige is, is daar ook ' $n$ inhoudelike voortsetting wat inpas by die formele. Die eer van Yahweh kom in die tweede stige weer voor. Nou word gesê dat hierdie eer deur kindertjies en suigelinge hemelhoog besing word ('al haššămayim is 'n voorsetselstuk wat die werkwoord kwalifiseer). Die derde stige bied nou weer die teendeel hiervan. Yahweh het sterkte opgestel vanweë $\left(l^{e} m a^{c} a n\right)$ sy teenstanders sodat $\mathrm{Hy}$ hulle kan vernietig (die vyand en die wraakgierige is dus omskrywings van die teenstanders). So staan stiges 2 en 3 in 'n antitetiese parallelisme. Aan die een kant is daar die teenstanders van Yahweh wat hulle teen Hom opstel. Dit is oormoed (hubris), want die omramende stige sê juis dat Yahweh se heerlikheid vir die hele aarde geld. Aan die ander kant staan die kinders en suigelinge. In so 'n antitetiese konteks is die kinders en suigelinge dan metafories gebruik. Hulle is die teengesteldes van die oormoedige teenstanders van Yahweh, dus die kleines en swakkes. Terwyl die een groep te gronde gaan, besing die ander groep die eer van Yahweh. Hierdeur word die kleinheid en nietigheid van die mens aangedui: Mense wat hulle teenoor Hom opstel en verhef, verkrummel. Daarteenoor mag die swakkelinge sy lof besing, dit wil sê $\mathrm{Hy}$ het behae in hulle. Beide stiges het dus dieselfde funksie: Aan die een kant word vanuit ' $n$ positiewe en aan die ander kant vanuit 'n negatiewe hoek aangetoon hoe nietig die mens voor Yahweh is. 
Vanweë hierdie sterk parallelisme mag ons dan ook stiges 2 en 3 aan mekaar verbind.

In 'n tussenopmerking kan reeds gewys word op die paradoksale verskynsel in stige 2: Die mens as 'n nietige figuur het positiewe waarde. Dit is 'n suggestie van wat deur die tweede helfte uitgebou sal word. Ons sal later sien hoe hierdie suggestiewe antisipasie uitgewerk word.

In stiges 4 en 5 word ' $n$ voorwaardelike konstruksie gevind: As ek die hemele, maan en sterre bekyk, wat is die mens dat $U$ aan hom dink en $\mathrm{U}$ met hom ophou ( $p q d)$ ? Hier kan ons duidelik sien dat die vraag ' $n$ retoriese vraag is (in die feit dat hy die apodosis uitmaak). Dit wil sê te midde van die skepping sien die mens klein en nietig daaruit sodat dit verbasend is dat Yahweh Hom met so 'n nietigheidjie ophou. Weer dus 'n suggestie van die paradoks: Dié Yahweh wie se heerlikheid besing is, hou Hom op met nietige mensies. So bepaal ons kontekstueel dat die mens hier onder die aspek van humilitas uitgebeeld word. Dit kan nie gedoen word deur te beweer dat 'enōs die swakheid van die mens aandui omdat die stam 'nt "swak wees" sou beteken het nie en ewe min dat 'ādām die verganklikheid van die mens aandui omdat dit van 'a dama, "grond" afhanklik sou wees (vergelyk die kommentaar van Hans-Joachim Kraus vir laasgenoemde).

Daarteenoor staan nou 'n tweede kwatryn wat 'n ander dimensie skep. Stige 6 sê dat Yahweh die mens net 'n bietjie minder as God gemaak het. Dit wil sê niks kan groter of heerliker wees as die mens nie. Dit word verder gekwalifiseer deur te sê dat die mens met $k a \bar{b} b \bar{d} d$ en $h \bar{a} d \bar{a} r$ gekroon $\left({ }^{c} t \underline{r}\right)$ is. Dié terme is almal tipies van die koninklike terminologie (vergelyk Ps 21:6). Derhalwe gee hulle deur hul konnotasie te kenne dat die mens ' $n$ koning is. Dit word bevestig deur die volgende drie stiges waar gesê word dat Yahweh die mens as heerser aangestel het (mśl hif ${ }^{c}$ il) oor alles wat Yahweh gemaak het. Die kol word deur 'n katalogus van die ander lewende wesens uitgebou. Vanweë hierdie stige-simmetrie mag ons dan ook 6 en 7 aan mekaar verbind vanweë hul gelyke bou en netso 8 en 9 omdat hulle parallel as ' $n$ katalogus funksioneer. Dit weerspreek nie ons eerste struktuuranalise nie, maar raffineer en verfyn dit:

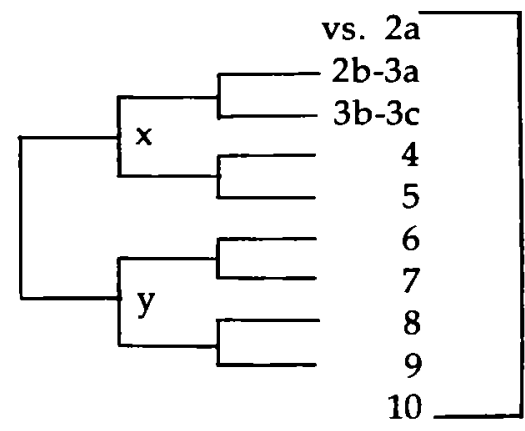


Hierdie twee strofes oor humilitas en dignitas van die mens staan nou nie sommer verniet langs mekaar nie. Hulle is tot 'n hegte eenheid verbind deur die omringende vers en ook deur die voegwoord $w^{e}$ wat die $y$-kwatryn aan die $x$-kwatryn verbind. Dus staan humilitas van die mens in verbànd met dignitas. Hier kan ons nou die antisiperende suggestie wat reeds in die eerste kwatryn voorgekom het, verstaan. Daar het ons reeds gesien dat daar 'n paradoksale verband bestaan tussen die kleintjies (wat positief met die besing van Gods eer verbind is) en hul aanvaarding, en eweneens 'n paradoks tussen die oormoedige teenstanders van God en hul vernedering. So dui die konteks van beide kwatryne nou in volheid aan dat die mens se $h u$ militas gepaard gaan met sy dignitas. Die kleine is die heerser. Dus: Die mens se grootheid bestaan juis in sy kleinheid. En dit is ook nie verniet dat alles deur die grote heerlikheid van God omspan word nie. Ook dit is reeds deur die antisiperende eerste kwatryn gesuggereer: Waar dit om Gods grootheid gaan, word menslike verhoudings omgekeer. In die konteks van Gòds grootheid word menslike swakheid en kleinheid groot, en menslike grootheid en mag bestaan alleen daarin dat Gòd dit gee - terwyl menslike selfverheffing téén God as swakheid ontmasker word. Dit is juis die wonderbaarlike van Gòds mag wat in die omramende stige besing word: Hy keer menslike magsverhoudings om.

\section{E. Tradisie}

In die eerste skeppingsverhaal word die mens eweneens as kroon van die skepping voorgestel, en wel ook in heerstersterme. Hier in Psalm 8 kom die imago Dei nie as motief voor nie, maar $m^{e c} a t$ me $e^{\prime} l o-$ him kom naby daaraan. Dit is ook in Egipte bekend, waar die koning as beelddraer van die godheid en as 'n goddelike heerser voorgestel word. Maar in die Ou Testament is die voorstelling geherinterpreteer om die mensheid te omvat - dus is dit gedemokratiseer en in die $\mathrm{Ou}$ Testamentiese Yahwehgeloof geintegreer. Die mens is nie ' $n$ goddelike heerser nie, maar' $n$ heerser in opdrag van God.

\section{F. Prediking}

Paulus ken ook die beroemde magsparadoks in I Korintiërs 1. Maar dit beteken nie dat ons nou eers moet lees wat hý sê voordat ons Psalm 8 kan verstaan nie. Selfs al het die Nuwe Testament nooit die magsparadoks gebruik nie, sou Psalm 8 nòg Gods woord gewees het en nòg vir die Christelike gemeente die boodskap gedra het van dignitas in humilitas. In die lig van die ganse Christusgebeure bekom die paradoks van Psalm 8 ook vir ons predikende waarde:

Algemeen: Die kroon vir mense in hul nederigheid. Geen menslike heerlikheid sonder erkenning van en buiging voor God nie. 
Spesifiek: Die heerskappy van die mens oor die skepping as genadegawe van God en dus onderhewig aan Hom. Die menslike waardigheid hou in dat hy met erkenning van die grense van sy mag oor die skepping sal heers. Sy heerskappy en ontwikkeling mag dus nie ten koste van die skepping en die behoud daarvan wees nie.

Geen minagting vir menslike waardigheid nie. Alle mense is deur God dignitas gegee. Maar ook geen oorwaardering daarvan asof die mens in die middelpunt van alles staan nie, want die mens is ' $n$ nietige wese. 